Improving the Utility of Evidence Synthesis for Decision Makers in the Face of Insufficient Evidence

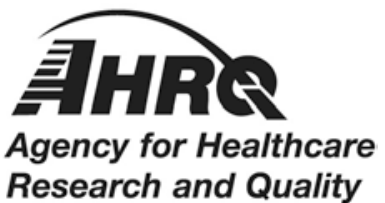




\title{
Improving the Utility of Evidence Synthesis for Decision Makers in the Face of Insufficient Evidence
}

\author{
Prepared for: \\ Agency for Healthcare Research and Quality \\ U.S. Department of Health and Human Services \\ 5600 Fishers Lane \\ Rockville, MD 20857 \\ www.ahrq.gov
}

Contract No. 290-2017-00003-C

Prepared by: Scientific Resource Center

Portland, OR

\section{Investigators:}

M. Hassan Murad, M.D., M.P.H.

Stephanie M. Chang, M.D., M.P.H.

Celia Fiordalisi, M.S.

Jennifer S. Lin, M.D., M.C.R.

Timothy J. Wilt, M.D., M.P.H.

Amy Tsou, M.D., M.Sc.

Brian Leas, M.S.

Shazia Siddique, M.D., M.S.H.P.

Andrew R. Zullo, Pharm.D., Ph.D.

Ethan Balk, M.D., M.P.H.

Carolyn M. Rutter, Ph.D.

Karen Robinson, Ph.D.

Craig Coleman, Pharm.D.

Olivia Costa, Pharm.D.

Elizabeth Stoeger, B.S.

Mark Helfand, M.D., M.P.H.

Meera Viswanathan, Ph.D.

AHRQ Publication No. 21-EHC007

April 2021 
This work was funded by the Agency for Healthcare Research and Quality through the following contracts: Scientific Resource Center (290-2017-00003-C), Mayo Clinic EPC (290-2015-00013I), Minnesota EPC (290-2015-00008-I), Kaiser Permanente EPC (290-2015-00007-I), RTIUniversity of North Carolina EPC (290-2015-00011-I), Southern California/RAND EPC (2902015-00010-I), Brown University EPC (290-2015-00002-I), ECRI Institute-Penn Medicine EPC (290-2015-00005-I), University of Connecticut EPC (290-2015-00012-I), and Johns Hopkins University EPC (290-2015-00006-I). The findings and conclusions in this document are those of the authors, who are responsible for its contents; the findings and conclusions do not necessarily represent the views of AHRQ. Therefore, no statement in this report should be construed as an official position of AHRQ or of the U.S. Department of Health and Human Services.

\section{None of the investigators have any affiliations or financial involvement that conflicts with the material presented in this report.}

The information in this report is intended to help healthcare decision makers - patients and clinicians, health system leaders, and policymakers, among others-make well-informed decisions and thereby improve the quality of healthcare services. This report is not intended to be a substitute for the application of clinical judgment. Anyone who makes decisions concerning the provision of clinical care should consider this report in the same way as any medical reference and in conjunction with all other pertinent information, i.e., in the context of available resources and circumstances presented by individual patients.

This report is made available to the public under the terms of a licensing agreement between the authors and the Agency for Healthcare Research and Quality. This report may be used and reprinted without permission except those copyrighted materials that are clearly noted in the report. Further reproduction of those copyrighted materials is prohibited without the express permission of copyright holders.

AHRQ or U.S. Department of Health and Human Services endorsement of any derivative products that may be developed from this report, such as clinical practice guidelines, other quality enhancement tools, or reimbursement or coverage policies, may not be stated or implied.

AHRQ appreciates appropriate acknowledgment and citation of its work. Suggested language for acknowledgment: This work was based on an evidence report, Improving the Utility of Uncertain Findings in Systematic Reviews for Healthcare Decisionmakers, by the Evidence-based Practice Center Program at the Agency for Healthcare Research and Quality (AHRQ).

Suggested citation: Murad MH, Chang SM, Fiordalisi C, Lin JS, Wilt TJ, Tsou A, Leas B, Siddique S, Zullo A, Balk E, Rutter CM, Robinson K, Coleman C, Costa O, Stoeger E, Arkhipova-Jenkins I, Helfand M, Viswanathan M. Improving the Utility of Evidence Synthesis for Decision Makers in the Face of Insufficient Evidence. Methods White Paper. (Prepared by the Scientific Resource Center under Contract No. 290-2017-00003-C.) AHRQ Publication No. 21-EHC007. Rockville, MD: Agency for Healthcare Research and Quality. April 2021. Posted final reports are located on the Effective Health Care Program search page. DOI:

10.23970/AHRQEPCWHITEPAPERIMPROVING. 


\section{Preface}

The Agency for Healthcare Research and Quality (AHRQ), through its Evidence-based Practice Centers (EPCs), sponsors the development of evidence reports and technology assessments to assist public- and private-sector organizations in their efforts to improve the quality of healthcare in the United States. The reports and assessments provide organizations with comprehensive, science-based information on common, costly medical conditions and new healthcare technologies and strategies. The EPCs systematically review the relevant scientific literature on topics assigned to them by AHRQ and conduct additional analyses when appropriate prior to developing their reports and assessments.

To improve the scientific rigor of these evidence reports, AHRQ supports empiric research by the EPCs to help understand or improve complex methodologic issues in systematic reviews. These methods research projects are intended to contribute to the research base in and be used to improve the science of systematic reviews. They are not intended to be guidance to the EPC program, although may be considered by EPCs along with other scientific research when determining EPC program methods guidance.

AHRQ expects that the EPC evidence reports and technology assessments will inform individual health plans, providers, and purchasers as well as the healthcare system as a whole by providing important information to help improve healthcare quality. The reports undergo peer review prior to their release as a final report.

If you have comments on this Methods Research Project they may be sent by mail to the Task Order Officer named below at: Agency for Healthcare Research and Quality, 5600 Fishers Lane, Rockville, MD 20857, or by email to epc@ahrq.hhs.gov.

David Meyers, M.D. Acting Director

Agency for Healthcare Research and Quality
Arlene Bierman, M.D., M.S.

Director

Center for Evidence and Practice Improvement

Agency for Healthcare Research and Quality

Stephanie Chang, M.D., M.P.H.

Director, Task Order Officer

Evidence-based Practice Center Program

Center for Evidence and Practice Improvement

Agency for Healthcare Research and Quality 


\section{Improving the Utility of Evidence Synthesis for Decisionmakers in the Face of Insufficient Evidence}

\section{Structured Abstract}

Background: Healthcare decision makers strive to operate on the best available evidence. The Agency for Healthcare Research and Quality Evidence-based Practice Center (EPC) Program aims to support healthcare decision makers by producing evidence reviews that rate the strength of evidence. However, the evidence base is often sparse or heterogeneous, or otherwise results in a high degree of uncertainty and insufficient evidence ratings.

Objective: To identify and suggest strategies to make insufficient ratings in systematic reviews more actionable.

Methods: A workgroup comprising EPC Program members convened throughout 2020. We conducted interative discussions considering information from three data sources: a literature review for relevant publications and frameworks, a review of a convenience sample of past systematic reviews conducted by the EPCs, and an audit of methods used in past EPC technical briefs.

Results: Several themes emerged across the literature review, review of systematic reviews, and review of technical brief methods. In the purposive sample of 43 systematic reviews, the use of the term "insufficient" covered both instances of no evidence and instances of evidence being present but insufficient to estimate an effect. The results of the literature review and review of the EPC Program systematic reviews illustrated the importance of clearly stating the reasons for insufficient evidence. Results of both the literature review and review of systematic reviews highlighted the factors decision makers consider when making decisions when evidence of benefits or harms is insufficient, such as costs, values, preferences, and equity. We identified five strategies for supplementing systematic review findings when evidence on benefit or harms is expected to be or found to be insufficient, including: reconsidering eligible study designs, summarizing indirect evidence, summarizing contextual and implementation evidence, modelling, and incorporating unpublished health system data.

Conclusion: Throughout early scoping, protocol development, review conduct, and review presentation, authors should consider five possible strategies to supplement potential insufficient findings of benefit or harms. When there is no evidence available for a specific outcome, reviewers should use a statement such as "no studies" instead of "insufficient." The main reasons for insufficient evidence rating should be explicitly described. 


\section{Contents}

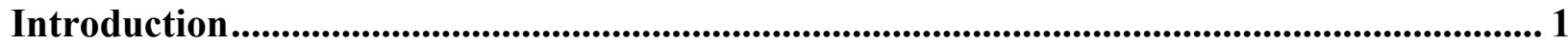

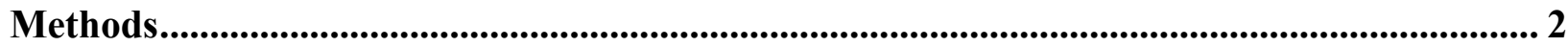

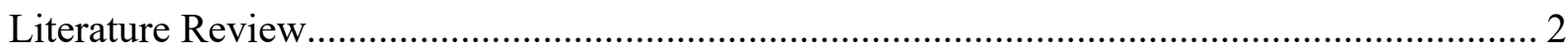

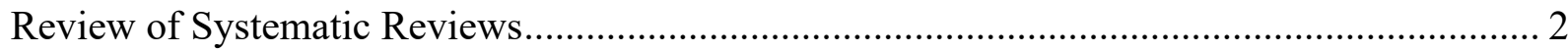

Audit of Technical Briefs................................................................................................... 3

Workgroup Discussion and Consensus Process .................................................................... 3

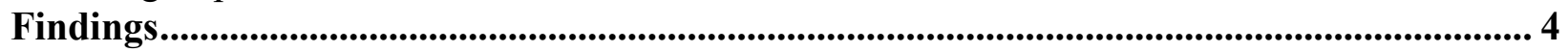

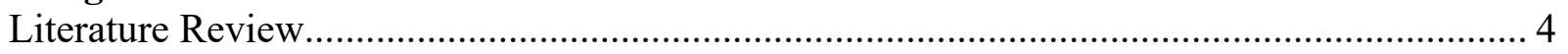

Review of Systematic Reviews........................................................................................ 4

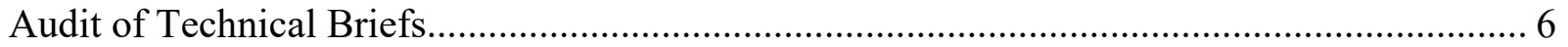

Strategies To Improve Utility of Insufficient Evidence ........................................................ 8

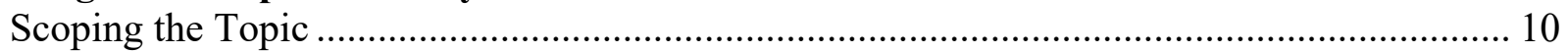

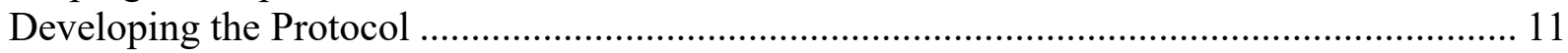

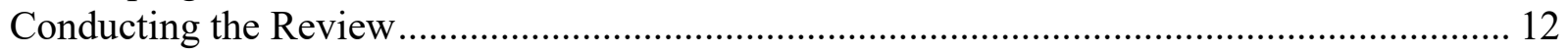

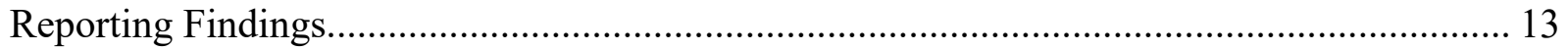

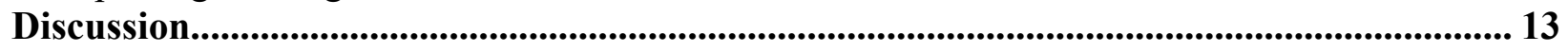

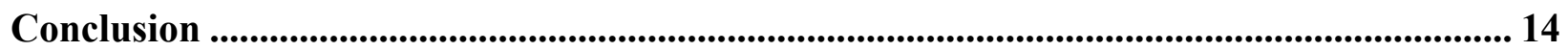

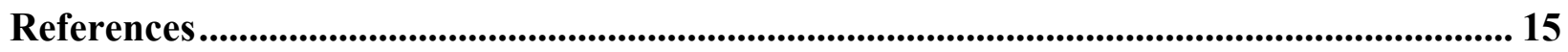

Abbreviations and Acronyms ..................................................................................................... 18

\section{Tables}

Table 1. Strategies to consider when developing the protocol for a review in which insufficient

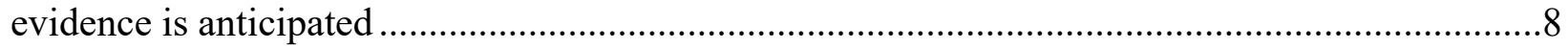

Table 2 . Review purposes and early decisions about synthesis approach ...............................11

Table 3. Potential strategies to address insufficient evidence.................................................12

\section{Appendixes}

Appendix A. Search Strategies

Appendix B. Literature Review

Appendix C. Review of Systematic Reviews

Appendix D. Review of Technical Briefs 


\section{Introduction}

Systematic reviewers synthesize a body of evidence and rate the strength of evidence available for each eligible outcome based on study limitations, consistency, directness, precision, and additional factors. When criteria are not adequately met, evidence may be rated as "insufficient." The phrase "insufficient strength of evidence" is used by the Agency for Healthcare Research and Quality's (AHRQ) Evidence-based Practice Center (EPC) Program to indicate, "We have no evidence, we are unable to estimate an effect, or we have no confidence in the estimate of effect for this outcome. No evidence is available or the body of evidence has unacceptable deficiencies, precluding reaching a conclusion." 1 By contrast, the lowest category of GRADE certainty of evidence ratings is "very low," which is defined as, "We have very little confidence in the effect estimate [for this outcome]. The true effect is likely to be substantially different from the estimate of effect." "

The term "insufficient," may be interpreted differently by various end-users of the review and may refer to different limitations of a given literature base. In the absence of qualifiers, readers of systematic reviews may conflate the insufficiency of evidence about an effect (e.g., on benefits or harms on a particular population, intervention, comparison or outcome) with the insufficiency of information to make a decision. Insufficient evidence does not necessarily mean that decisionmakers will not or should not act on the evidence that is available. In fact, healthcare decision makers consider evidence as one of many decisional factors, which may include patient and healthcare provider values and preferences, resources, feasibility, acceptability of the recommended actions, ${ }^{3}$ and concerns about inaction. When there is no evidence or insufficient evidence on benefits or harms, information on these other factors may be important to summarize for decision makers. ${ }^{4}$

A workgroup from the AHRQ EPC Program sought to understand how systematic reviewers can support decision making in the face of insufficient evidence. The workgroup aimed to identify (1) the various ways in which the term "insufficient evidence" has been used, defined, and understood in the literature; (2) published frameworks for decision-making based on insufficient evidence; and (3) strategies that can be adopted by systematic reviewers to provide additional information to support decision making when facing insufficient evidence. Finally, the workgroup provided recommendations for systematic reviewers on how to handle insufficient evidence during scoping of the topic, developing the protocol, and conducting and reporting the review. 


\section{Methods}

A workgroup comprised members from 9 EPCs (RTI International-University of North Carolina, Mayo Clinic, ECRI Institute-Penn Medicine, University of Minnesota/Minneapolis VA, Brown University, Kaiser Permanente, Southern California/RAND, Johns Hopkins University, University of Connecticut), AHRQ, and the Scientific Resource Center (SRC). We met twice monthly for 10 months and gathered additional input from the wider EPC Program at two virtual meetings. This report draws on three sources of data: a literature review, a review of a purposive sample of EPC reports that identified insufficient evidence, and an audit of EPC technical briefs. Technical briefs were reviewed because they are often prepared for topics where there is anticipated to be a small body of direct evidence. Technical briefs may answer foundational and definitional questions in addition to (or instead of) questions of benefits and harms and may use a variety of information sources to guide report writing or support decision making. Strategies were subsequently identified and suggested based on the three data sources and iterative discussions among the workgroup members.

\section{Literature Review}

The SRC staff librarian conducted two literature searches (see Appendix A) to identify articles describing insufficient evidence in terms of: (1) how it was defined or acted on in decision making or guideline development and (2) how different audiences might react to the term "insufficient." The research librarian conducted a first-pass abstract and title screening to exclude irrelevant references. The two workgroup leads screened the remaining citations to select articles for inclusion. The workgroup members evaluated the included full-text papers for relevance and extracted pertinent information into a standardized form. The two workgroup leads categorized the articles into five topic areas: (1) types and definitions of insufficient evidence, (2) existing frameworks to rate insufficient evidence, (3) decision making in the face of insufficient evidence, (4) evidence synthesis and insufficient evidence, and (5) other miscellaneous themes. The workgroup organized results thematically and used these findings to identify potential recommendations.

\section{Review of Systematic Reviews}

To uncover how EPCs currently classify and present insufficient evidence ratings, we reviewed a purposive sample of systematic reviews previously published by the EPCs. Twelve EPCs were asked to select their own examples of at least five examples of systematic reviews, either AHRQ funded or non-AHRQ funded, that were completed during the last 5 years, in which at least one Key Question had insufficient evidence. Systematic reviews with a specific sponsor or stakeholder were prioritized because these reflect scenarios when the review was most likely carried out to directly inform decisionmaking.

For each included review, workgroup members (or a volunteer from the EPC if the EPC was not already represented on the workgroup) extracted information pertaining to the decisional dilemma addressed by the review, whether the insufficient evidence rating was anticipated at the start of the review, reasons for insufficient evidence ratings, any approaches used to address the insufficient evidence and help decision makers act on the evidence, and whether the main stakeholder of the review made any recommendations based on the insufficient evidence. 


\section{Audit of Technical Briefs}

Members of the SRC extracted information from 21 technical briefs accepted for publication by the AHRQ EPC Program between May 2014 and February 2020. Technical briefs often combine multiple sources of information (Key Informant [KI] interviews, published literature, grey literature, audits of commercially available products) and they consider practical aspects of implementing various clinical or quality improvement interventions.

Aside from traditional evidence sources, such as systematic reviews and primary literature, many briefs also explored sources of data not typically used in systematic reviews, such as websites of commercially available products, ${ }^{5-7}$ clinical practice guidelines, ${ }^{8,9}$ and numerous sources of grey literature(like reports published by state and county health officials). ${ }^{10}$

Therefore, we reviewed data sources and analytic approaches that have been used in technical briefs. Our review also reported the methods used in technical briefs when the questions summarized contextual and implementation information. As a proxy to determine whether the intended audience was satisfied with the report and methods used, the SRC examined peer and public review comments on the draft technical brief. The SRC also considered summaries from the topic nominator to better elucidate the decisional dilemma faced by the end-user a priori to commissioning the technical brief. From the technical brief reports, peer and public comment summaries, and nomination summaries, the SRC extracted information pertaining to the reports' decisional dilemma, a subjective determination of how well the technical brief research questions directly addressed that dilemma, evidence synthesis methods, and whether peer and public reviewers recommended substantial changes to the synthesis, conduct, or framing of the report. The SRC and EPC workgroup then reviewed the extracted data to identify common themes.

\section{Workgroup Discussion and Consensus Process}

The method for determining consensus of these strategies was informal. We discussed issues until no one voiced disagreements. 


\section{Literature Review}

\section{Findings}

The initial literature search identified 1,458 articles for review; after title and abstract screening 208 references remained. After full-text screening, 73 articles were included in the final review. Of these, the workgroup members judged 44 to be relevant. The articles included methodology framework papers, systematic reviews, commentaries, opinion pieces, consensus documents, and qualitative studies. The reviewed documents are summarized in Appendix B. The relevant literature was classified into the following five categories:

1. Types and definitions of insufficient evidence $(n=5)$ : these papers differentiated insufficient evidence due to

a. having no evidence;

b. imprecision (small number of events and large variance);

c. other reasons leading to an inability to make a decision despite being able to estimate effect size.

2. Frameworks for rating insufficient evidence $(n=2)$ : these papers identified frameworks and definitions of insufficient evidence, such the United States Preventive Services Task Force (USPSTF) approach. ${ }^{11}$

3. Decisionmaking with insufficient evidence $(n=27)$ : these papers discussed

a. challenges of decisionmaking in light of insufficient evidence;

b. the difficulty of identifying relevant evidence to guide decisions in children, rare diseases, and in primary care settings;

c. patients' dissatisfaction with uncertainty;

d. decisionmaking using local health system data (such as data from electronic medical records) when the evidence was insufficient;

e. healthcare providers preference for having a recommendation about management even if the evidence was insufficient to support the recommendation.

4. Evidence synthesis and insufficient evidence $(n=1)$ : this paper suggested providing additional interpretation and extrapolation by content experts, that was labeled on one occasion "rigorous speculation," to improve evidence uptake when the evidence is insufficient. ${ }^{4}$

5. Other themes $(n=9)$ : these papers discussed

a. interpretation of $p$-values;

b. value of cost effectiveness analysis;

c. the unique setting of coverage decisions;

d. making guideline recommendations using GRADE that are strong recommendations based on weak evidence. ${ }^{12}$

\section{Review of Systematic Reviews}

Nine EPCs analyzed 43 purposefully selected systematic reviews. These reviews are summarized in Appendix C. Of these, 29 (67\%) were commissioned by the AHRQ EPC Program. Other entities that commissioned reviews included international non-for-profit organizations (e.g, the World Health Organization), state (e.g., State of Washington) and federal entities (e.g, Department of Defense, Veterans Administration), professional societies (e.g, the American College of Rheumatology, American Society of Hematology, Endocrine Society, and Kidney Disease: Improving Global Outcomes), and academic health systems. The American 
Academy of Child and Adolescent Psychiatry and the USPSTF were most commonly reported as end-users.

The reviews varied in terms of how the decisional dilemma was phrased. Many statements of the decisional dilemma were specific, and included a clear statement of the population, intervention, and outcome (e.g., "Should disulfiram be recommended to reduce alcohol use or increase abstinence in adolescents with alcohol use disorder?"). A few reported a decisional dilemma but phrased it in broader terms (e.g., "To screen or not to screen").

\section{Definition of the Term "Insufficient"}

In the 43 systematic reviews, the use of the term "insufficient" covered both instances of no evidence (i.e., no studies directly evaluated the population, intervention, or outcome of interest; or no studies directly evaluated the research question) and instances of evidence being present but insufficient to estimate an effect (or to make a conclusion). Although the reasons for rating evidence as insufficient frequently pertained to imprecision and lack of evidence, other reasons were high risk of bias in individual studies, and inconsistency among evaluated studies.

\section{Adding Information Sources to Address the Decisional Dilemma in the Context of Insufficient Evidence}

Twenty-six $(60 \%)$ of the reviews included specific solutions to help address the decisional dilemma in the context of insufficient evidence. In 21 (49\%) reviews, the finding of insufficient evidence was anticipated by the review team (e.g., the systematic review was an update of a previous one, or scoping the literature indicated lack of evidence). When authors found insufficient evidence for specific outcomes, one set of solutions included summarizing the evidence for ineligible populations, interventions (i.e., indirect evidence), and study designs in the discussion section of the report. A second solution involved providing information on other important factors (not addressed as Key Questions) that may be used to inform decisionmaking; these were addressed as contextual questions. A third solution involved revising the review criteria to include observational study designs.

Systematic reviewers offered examples of how they summarized results outside the review parameters. For example, a review on screening and early treatment for asymptomatic peripheral artery disease with the ankle-brachial index included limited data on screening accuracy in their target population (asymptomatic general population). ${ }^{13}$ To address this, in the discussion section of the report, they supplemented the review with a summary of the larger evidence base on screening accuracy in populations symptomatic for peripheral arterial disease, recognizing that extrapolation may exaggerate the diagnostic accuracy. ${ }^{13}$ As an example of interventions outside the scope of the review, an evaluation of screening for atrial fibrillation with electrocardiograms included information on screening with electrocardiograms for atherosclerotic cardiovascular disease. $^{14}$

Regarding presenting contextual information, several examples came from reviews conducted for the USPSTF, which has an established process for summarizing and using contextual information for conceptual bounding of benefits and harms. ${ }^{11}$ For example, this process might involve presenting information on incidence of the harm in a narrower population, so that the incidence in the general population (with lower risk) can be inferred as very low. Other contextual information pertained to the "diagnostic odyssey of the families" for whole exome sequencing ${ }^{15}$ and the "penetrance/prevalence" of multigene panels for hereditary breast 
cancer risk assessment test. ${ }^{16}$ Some reviewers described compiling contextual information in a rigorous manner (relying on systematic reviews and targeted searches); two specifically mentioned clinical judgment and expert opinion.

\section{Making Recommendations Despite Insufficient Evidence}

Several systematic reviews sponsored by guideline developers described their end-users as making recommendations in the context of insufficient evidence. In these instances, contextual information supported recommendations for or against the treatment. In a review of whole exome sequencing, the end-user "acknowledged the limitations in the evidence, but in the end recognized the very specific contextual circumstances regarding use of this test, and felt that there was enough of a signal of potential benefit, without significant harms and with some evidence of cost-effectiveness that it could be reasonable to use by qualified professionals (i.e. medical geneticists) according to specified criteria for use." "Another example was a recommendation against screening asymptomatic patients with sickle cell disease with pulmonary function tests. ${ }^{17}$ The evidence supporting benefits was deemed insufficient but considering the cost and inconvenience of pulmonary function testing, particularly in children, the panel made a recommendation against testing.

\section{Audit of Technical Briefs}

A total of 21 technical briefs were included in this audit. A full listing of the 21 reports included in this audit and a summary data abstraction table can be found in Appendix D. Sixteen $(76 \%)$ discussed information from Key Informant (KI) interviews within the findings of their report and were not simply being used to assist topic scoping. KI interviews were used to summarize contextual or implementation factors and to develop conceptual frameworks or tables of theoretical advantages and disadvantages of an intervention. Two technical briefs reported using formal qualitative research methodology to analyze content from KI interviews. ${ }^{18,19}$

Many technical brief questions focused on practical aspects of decisional dilemmas, such as context in which interventions have been studied, implementation strategies for various interventions, or barriers and facilitators affecting implementation. Fifteen (71\%) included a Guiding Question pertaining to contextual or implementation factors. For example, the report "Characteristics of Existing Asthma Self-Management Education Packages" interviewed KIs to identify practical barriers to effective implementation of chronic asthma selfmanagement/education packages. ${ }^{6}$ KIs revealed the need to consider factors well beyond the instructional content of these packages, such as patient demographics, health literacy levels, and access issues such as the availability of health insurance coverage. Another technical brief that assessed the available evidence regarding strategies for comprehensive health management for women with HIV/AIDS used input from clinicians and social workers to devise a series of clinical vignettes to illustrate complex psychosocial and other contextual issues commonly encountered in the care of these patients. ${ }^{20}$

Technical briefs also often include analyses of data sources beyond what is typically included in systematic reviews. For example, "Pharmacologic and Nonpharmacologic Treatments for Posttraumatic Stress Disorder: Groundwork for a Publicly Available Repository of Randomized Controlled Trial Data" " and "Treatment for Acute Pain: An Evidence Map" both included clinical practice guidelines. "Skin Substitutes for Treating Chronic Wounds,"7 "Characteristics of Existing Asthma Self-Management Education Packages," and "Decision Aids for Advance Care Planning" 21 all abstracted characteristics of commercially available products from industry 
web pages. The review "Impact of Community Health Worker Certification on Workforce and Service Delivery for Asthma and Other Selected Chronic Diseases"10 included reports published by State and county health officials on certification requirements posted on state health department web pages.

Data sources for evaluating representativeness of initial decisional dilemma in report scoping and subsequent end-user satisfaction were not as readily available as initially anticipated. Additional efforts are being taken outside of this workgroup by the SRC and AHRQ to more easily link topic nomination decisional dilemma details and feedback with eventual published reports. Published disposition of comments tables for technical briefs were the most readily available proxy measure, but they should be interpreted cautiously and more as clues for future improvements rather than sources to identify problems with past methods.

Of the 16 technical briefs that included KI information within the findings of their report, 8 had requests from peer reviewers suggesting samples may not have been representative of all relevant stakeholders (6 reports) or all relevant information did not come out of interviews (2 reports), which could be related to an insufficiently representative sample of KIs. Formal qualitative methods rely on representative samples and utilize interview techniques to reach thematic saturation. Since technical briefs did not always reach thematic saturation, more formal qualitative methods may be useful in providing findings that include the content of importance to end-users. Peer reviewers asked for patient advocates or front-line clinicians to be included as KIs, and often questioned the selection process for KIs.

Peer reviewers often asked for an expanded scope of the technical brief to include costs, additional populations, interventions, or settings. 


\section{Strategies To Improve Utility of Insufficient Evidence}

The literature review, review of systematic reviews, audit of technical briefs, and iterative discussions amongst workgroup members contributed to the development of the following strategies that may be used to supplement findings of insufficient evidence. We identified five strategies: (1) reconsider eligible study designs, (2) summarize indirect evidence, (3) summarize contextual and implementation evidence, (4) consider modelling, and (5) incorporate unpublished health system data in the evidence synthesis (e.g., a primary observational study that uses data from the electronic medical record of the health system). Table 1 describes these strategies with examples. Some of these strategies are consistent with best practices regardless of anticipated strength of evidence. When reviewers adopt a strategy, they should follow the methodological guidance relevant to the chosen strategy (e.g., best practices of qualitative synthesis or modelling) to maintain the rigor and reproducibility.

Table 1. Strategies for addressing insufficient evidence in evidence synthesis programs*

\begin{tabular}{|c|c|c|c|}
\hline Strategy & Description & Example & Example Description \\
\hline $\begin{array}{l}\text { Reconsider eligible study } \\
\text { designs }\end{array}$ & $\begin{array}{l}\text { In designing the original } \\
\text { protocol, authors may } \\
\text { have anticipated sufficient } \\
\text { evidence from stronger } \\
\text { designed studies. } \\
\text { However, if potential bias } \\
\text { in design or conduct of the } \\
\text { study leads to insufficient } \\
\text { evidence, authors may } \\
\text { reconsider inclusion of } \\
\text { observational studies, } \\
\text { studies without } \\
\text { comparisons or other } \\
\text { study designs. }\end{array}$ & $\begin{array}{l}\text { Whole Exome } \\
\text { Sequencing: Final } \\
\text { Evidence Report }{ }^{15}\end{array}$ & $\begin{array}{l}\text { The systematic review } \\
\text { was conducted to support } \\
\text { a recommendation for or } \\
\text { against whole exome } \\
\text { sequencing. The review } \\
\text { summarized the results } \\
\text { from single arm studies in } \\
\text { addition to modeling } \\
\text { studies and studies with } \\
\text { comparator arms. }\end{array}$ \\
\hline $\begin{array}{l}\text { Summarize evidence } \\
\text { outside the prespecified } \\
\text { review parameters } \\
\text { (indirect evidence) }\end{array}$ & $\begin{array}{l}\text { Evidence may be sought } \\
\text { from studies excluded } \\
\text { during the review process } \\
\text { due to different } \\
\text { populations, interventions, } \\
\text { comparators, and } \\
\text { settings. These excluded } \\
\text { studies may have limited } \\
\text { applicability to the review } \\
\text { question; use of such } \\
\text { evidence requires } \\
\text { appropriate interpretation } \\
\text { and contextualization by } \\
\text { clinical experts. These } \\
\text { results may be } \\
\text { summarized as contextual } \\
\text { evidence or in the } \\
\text { discussion section of the } \\
\text { report. }\end{array}$ & $\begin{array}{l}\text { American Society of } \\
\text { Hematology } 2020 \\
\text { guidelines for sickle cell } \\
\text { disease: management of } \\
\text { acute and chronic pain }\end{array}$ & $\begin{array}{l}\text { A systematic review was } \\
\text { done to support guidelines } \\
\text { about the management of } \\
\text { pain in individuals with } \\
\text { sickle cell disease. Due to } \\
\text { paucity of data, the } \\
\text { EPCsummarized } \\
\text { published systematic } \\
\text { reviews on pain } \\
\text { management in conditions } \\
\text { other than sickle cell } \\
\text { disease that were deemed } \\
\text { clinically similar by the } \\
\text { guideline panel. }\end{array}$ \\
\hline
\end{tabular}




\begin{tabular}{|c|c|c|c|}
\hline Strategy & Description & Example & Example Description \\
\hline \multirow[t]{2}{*}{$\begin{array}{l}\text { Summarize evidence on } \\
\text { contextual factors (factors } \\
\text { other than benefits/harms) }\end{array}$} & $\begin{array}{l}\text { Example } 1 . \\
\text { Decisionmakers must } \\
\text { consider other factors } \\
\text { besides evidence on } \\
\text { effectiveness and harms } \\
\text { of an intervention. } \\
\text { Evidence on other factors } \\
\text { that may affect the } \\
\text { decision may be helpful to } \\
\text { decisionmakers, such as } \\
\text { patient values, equity, } \\
\text { resources, acceptability, } \\
\text { and feasibility. }\end{array}$ & $\begin{array}{l}\text { Comparative effectiveness } \\
\text { and safety of cognitive } \\
\text { behavioral therapy and } \\
\text { pharmacotherapy for } \\
\text { childhood anxiety } \\
\text { disorders: a systematic } \\
\text { review and meta-analysis }{ }^{9}\end{array}$ & $\begin{array}{l}\text { An EPC report about the } \\
\text { management of anxiety in } \\
\text { children compared the } \\
\text { different pharmacological } \\
\text { and nonpharmacological } \\
\text { treatments in terms of } \\
\text { benefits and harms. } \\
\text { Additional data were } \\
\text { summarized in a } \\
\text { subsequent report }{ }^{10} \text { that } \\
\text { included contextual and } \\
\text { implementation } \\
\text { information (doses of } \\
\text { common treatments, } \\
\text { which patients are } \\
\text { candidate for treatment, } \\
\text { values and preferences, } \\
\text { costs and resources, } \\
\text { acceptability, impact on } \\
\text { health equity, feasibility, } \\
\text { alternative therapies, } \\
\text { remission rates and } \\
\text { prognosis). Contextual or } \\
\text { implementation evidence } \\
\text { may require quantitative } \\
\text { or qualitative evidence } \\
\text { synthesis. }\end{array}$ \\
\hline & $\begin{array}{l}\text { Example } 2 . \\
\text { Studies examining the } \\
\text { effectiveness of complex } \\
\text { interventions may be } \\
\text { challenging to synthesize } \\
\text { because of heterogeneity } \\
\text { in interventions or } \\
\text { populations studied. } \\
\text { Realist reviews or } \\
\text { qualitative evidence } \\
\text { synthesis may be helpful } \\
\text { to explore reasons for } \\
\text { heterogeneity, and to } \\
\text { uncover specific } \\
\text { conditions under which a } \\
\text { complex intervention may } \\
\text { work better or worse. }\end{array}$ & $\begin{array}{l}\text { A systematic review of } \\
\text { qualitative evidence on } \\
\text { barriers and facilitators to } \\
\text { the implementation of } \\
\text { task-shifting in midwifery } \\
\text { services }^{11}\end{array}$ & $\begin{array}{l}\text { A qualitative evidence } \\
\text { synthesis examined the } \\
\text { qualitative literature to } \\
\text { report implementation } \\
\text { factors associated with } \\
\text { midwifery task shifting and } \\
\text { optimization. For this } \\
\text { complex intervention, the } \\
\text { question went beyond } \\
\text { asking if it works, but the } \\
\text { World Health Organziation } \\
\text { wanted to know how to } \\
\text { implement it in the most } \\
\text { effective way. The } \\
\text { qualitative evidence } \\
\text { synthesis elucidated } \\
\text { challenges and other } \\
\text { considerations when } \\
\text { implementing such } \\
\text { practices. }\end{array}$ \\
\hline $\begin{array}{l}\text { Consider modelling if } \\
\text { appropriate and expertise } \\
\text { is available }\end{array}$ & $\begin{array}{l}\text { Various types of modeling } \\
\text { such as decision analysis } \\
\text { can be used to fill gaps in } \\
\text { the evidence base. } \\
\text { Modelling is time intensive } \\
\text { but may be appropriate if } \\
\text { models exist that can be } \\
\text { adapted to address } \\
\text { research gaps }\end{array}$ & $\begin{array}{l}\text { Collaborative Modeling of } \\
\text { U.S. Breast, Lung, } \\
\text { Colorectal, and Cervical } \\
\text { Cancer Screening } \\
\text { Strategies }^{12}\end{array}$ & $\begin{array}{l}\text { The systematic review } \\
\text { addressed the question of } \\
\text { benefits and harms of } \\
\text { screening for breast } \\
\text { cancer. Modeling was } \\
\text { used to address specific } \\
\text { remaining gaps about } \\
\text { combinations of screening } \\
\text { modalities, frequency and } \\
\text { start age. }\end{array}$ \\
\hline
\end{tabular}




\begin{tabular}{|c|c|c|c|}
\hline Strategy & Description & Example & Example Description \\
\hline $\begin{array}{l}\text { Incorporate health system } \\
\text { data into a review }\end{array}$ & $\begin{array}{l}\text { Local health system data } \\
\text { can inform decision- } \\
\text { making by augmenting the } \\
\text { evidence base or by } \\
\text { informing implementation } \\
\text { efforts. }^{13}\end{array}$ & $\begin{array}{l}\text { Endovascular treatment of } \\
\text { internal carotid artery } \\
\text { bifurcation aneurysms: a } \\
\text { single-center experience } \\
\text { and a systematic review } \\
\text { and meta-analysis }{ }^{14}\end{array}$ & $\begin{array}{l}\text { To determine the } \\
\text { outcomes of endovascular } \\
\text { treatment of internal } \\
\text { carotid artery bifurcation } \\
\text { aneurysms, only } 6 \text { small } \\
\text { surgical series were found } \\
\text { in the literature (a total of } \\
\text { only } 158 \text { patients). } \\
\text { Reviewing the electronic } \\
\text { medical record of a single } \\
\text { health system (Mayo } \\
\text { Clinic), identified } 37 \\
\text { additional cases that were } \\
\text { incorporated into the } \\
\text { systematic review. This } \\
\text { addition increased the } \\
\text { size of the body of } \\
\text { evidence by } 23 \% \text { and } \\
\text { provided more granular } \\
\text { details on patients' clinical } \\
\text { characteristics, and thus, } \\
\text { may further support } \\
\text { decisionmaking in this } \\
\text { context, although it may } \\
\text { not increase strength of } \\
\text { evidence. }\end{array}$ \\
\hline
\end{tabular}

Acronym: EPC= Evidence-based Practice Center.

*These strategies may not always be logistically possible during the conduct of the review and may require a separate subsequent study.

\section{Scoping the Topic}

During the scoping stage, when a determination is being made whether a systematic review is of interest, of value, and is likely to have sufficient evidence to summarize, it may be possible to anticipate and plan for specific findings of insufficient evidence. Early identification and engagement of stakeholders can facilitate clear understanding of the decisional context and dilemma. This early partnership can also clarify the anticipated volume of the literature, timeline, and feasibility of the review. In this case, the specific question and approach can be discussed and modified if needed, the possibility of conducting a technical brief can be entertained, and the need for some of the approaches to address insufficient evidence can be determined (see below: Developing the Protocol, Conducting the Review).

For complex questions, including questions related to implementation, topic experts could offer a good source of information about the quantity and quality of available evidence. Care should be taken that all relevant stakeholders are represented and that interview methods are adequate to reach thematic saturation. Scoping of a review requires balance and consideration of the tradeoffs necessary to keep workloads manageable. See Table 1 for several examples of decisional dilemmas and approaches. 
Table 2. Review purposes and early decisions about synthesis approach

\begin{tabular}{|c|c|c|c|}
\hline Decisional Dilemma & Type of Question & Decisional Context & Approach \\
\hline $\begin{array}{l}\text { Does a test, strategy, or } \\
\text { intervention work? }\end{array}$ & $\begin{array}{l}\text { Accuracy or } \\
\text { Effectiveness/harms }\end{array}$ & $\begin{array}{l}\text { No other known effective } \\
\text { tests or interventions }\end{array}$ & $\begin{array}{l}\text { Effectiveness review, } \\
\text { technical brief if anticipate } \\
\text { insufficient evidence }\end{array}$ \\
\hline $\begin{array}{l}\text { Is a test, strategy, or } \\
\text { intervention better than } \\
\text { one or more alternatives? }\end{array}$ & $\begin{array}{l}\text { Comparative } \\
\text { accuracy/effectiveness or } \\
\text { harms }\end{array}$ & $\begin{array}{l}\text { There are existing } \\
\text { effective options, but a } \\
\text { "newer" intervention may } \\
\text { be more effective. }\end{array}$ & $\begin{array}{l}\text { Comparative effectiveness } \\
\text { review with established } \\
\text { minimally important } \\
\text { difference }\end{array}$ \\
\hline $\begin{array}{l}\text { Is a test, strategy, or } \\
\text { intervention as good as an } \\
\text { alternative? }\end{array}$ & $\begin{array}{l}\text { Comparative } \\
\text { accuracy/effectiveness } \\
\text { review }\end{array}$ & $\begin{array}{l}\text { There is an established } \\
\text { standard of care, but a } \\
\text { "newer" intervention is } \\
\text { expected to be cheaper or } \\
\text { have fewer harms. }\end{array}$ & $\begin{array}{l}\text { Comparative effectiveness } \\
\text { review with established } \\
\text { minimally important } \\
\text { difference. A modeling } \\
\text { study may also be } \\
\text { considered. }\end{array}$ \\
\hline $\begin{array}{l}\text { What is the "best" } \\
\text { approach among several } \\
\text { alternative tests, } \\
\text { strategies, or interventions } \\
\text { considering tradeoffs for } \\
\text { different outcomes? }\end{array}$ & Net benefit analysis & $\begin{array}{l}\text { Multiple comparisons, } \\
\text { each with different levels } \\
\text { of benefit and different } \\
\text { harms }\end{array}$ & Modeling study \\
\hline $\begin{array}{l}\text { How does a test, strategy, } \\
\text { or intervention work and } \\
\text { under what circumstance } \\
\text { does it work? }\end{array}$ & $\begin{array}{l}\text { Implementation of } \\
\text { complex intervention }\end{array}$ & $\begin{array}{l}\text { Multicomponent } \\
\text { interventions that are } \\
\text { likely to have } \\
\text { heterogeneous evidence }\end{array}$ & $\begin{array}{l}\text { Qualitative evidence } \\
\text { synthesis or complex } \\
\text { intervention } \\
\text { methodologies (such as } \\
\text { metaregression, finite } \\
\text { mixture models, or } \\
\text { qualitative comparative } \\
\text { analysis). }\end{array}$ \\
\hline
\end{tabular}

During the scoping stage, it may be possible to anticipate the finding of insufficient evidence. In this case, the specific question and approach can be discussed and modified if needed, the possibility of conducting a technical brief can be entertained, and the need for some of the approaches to address insufficient evidence can be determined (see below: Developing the Protocol, Conducting the Review).

\section{Developing the Protocol}

When developing the protocol, systematic review authors should again consider the most appropriate methods and inclusion criteria that are most likely to provide the information to answer the question. Authors should determine a priori the outcomes that require strength of evidence (SOE) grading (after accounting for stakeholder perspectives and needs, decisional context and dilemma), critical and important outcomes, and specific thresholds for determining benefit or harm) and consider what other questions and methods to use if there is insufficient evidence for an outcome critical for the stakeholder decision making process.

The stakeholder needs, decisional dilemmas, and context will determine the most appropriate outcomes for rating the SOE. As described in the EPC Methods Guide for Effectiveness and Comparative Effectiveness Reviews, systematic review authors must also decide a priori what outcomes are considered critical for grading. ${ }^{22}$ Review authors should also consider what additional questions and methods may be appropriate if evidence using the proposed criteria result in insufficient evidence. ${ }^{23}$ 
In planning for one or more of these strategies, reviewers should explicitly note if they are planning a "best evidence" approach ${ }^{23}$ which may start with more narrow inclusion criteria, but expand to other study designs or populations if evidence is insufficient. In anticipation of sufficient evidence, reviewers may decide to restrict to randomized controlled trials and/or to a specific target population. However, in the conduct of the study, reviewers may discover that flaws in the conduct of the study or overall imprecision or inconsistency lead to insufficient evidence. For reviews proposing a "best-evidence approach," reviewers should plan and describe in the protocol what types of other evidence (such as from different study designs, populations, comparators, or other types of contextual information) will be considered if initial eligibility criteria yields insufficient evidence. Identification of these other types of evidence at the protocol stage will allow reviewers to keep track of such types of evidence so that they can modify the workflow and improve the efficiency of retrieving studies or information as needed later. This approach is consistent with the EPC Methods Guide for Effectiveness and Comparative Effectiveness Reviews which recommends including nonrandomized studies if there is anticipated insufficient evidence from randomized controlled studies. ${ }^{24}$

\section{Conducting the Review}

Ideally, reviewers would anticipate insufficient evidence at the earlier stages of scoping the review or developing the protocol and plan for additional approaches of evidence synthesis. However, if systematic reviewers find insufficient evidence during the course of review and have the time and resources, they may consider these additional strategies based on the reasons for the rating or recommended the strategies for next steps or future research.

Table 3 describes potential reasons for insufficient evidence and corresponding methods that may be used to supplement insufficient ratings. Notably, in some instances, the suggested approaches may not be logistically feasible during the conduct of the review and may be appropriate to recommend for a subsequent study.

Table 3. Potential strategies to address insufficient evidence

\begin{tabular}{|c|c|}
\hline Reason for Insufficient Evidence & Potential Strategies \\
\hline $\begin{array}{l}\text { No or sparse evidence from } \\
\text { randomized controlled trials, or } \\
\text { most studies have high risk of bias }\end{array}$ & $\begin{array}{l}\text { - For reviews proposing a best-evidence approach, reconsider study } \\
\text { eligibility of other study designs } \\
\text { - Summarize evidence outside the prespecified review parameters } \\
\text { (indirect evidence). } \\
\text { - Summarize contextual information (other than evidence on } \\
\text { benefits/harms) } \\
\text { - Incorporate health system data into a review }\end{array}$ \\
\hline $\begin{array}{l}\text { Indirect outcomes, populations, } \\
\text { interventions, or settings }\end{array}$ & $\begin{array}{l}\text { - Summarize evidence outside the prespecified review parameters } \\
\text { (indirect evidence). } \\
\text { - Summarize contextual information (other than evidence on } \\
\text { benefits/harms) } \\
\text { - Consider modelling if appropriate and expertise is available } \\
\text { - Incorporate health system data into a review }\end{array}$ \\
\hline $\begin{array}{l}\text { Conflicting or heterogeneous } \\
\text { studies, particularly with complex } \\
\text { interventions or implementation } \\
\text { questions }\end{array}$ & $\begin{array}{l}\text { - Summarize contextual information (other than evidence on } \\
\text { benefits/harms) } \\
\text { - Conduct realist review/Qualitative evidence synthesis and/or } \\
\text { comparative analysis } \\
\text { - Incorporate health system data into a review }\end{array}$ \\
\hline
\end{tabular}


Notably, in some instances, these approaches may not be logistically feasible during the conduct of the review and may be appropriate to recommend for subsequent study. In other instances (e.g., rapid reviews in the context of known uncertainties), reviewers may need to plan for several simultaneous strategies.

\section{Reporting Findings}

Review authors should explicitly state when no studies are available (e.g., "no studies have directly evaluated this outcome, or no evidence available") instead of using the term "insufficient." Review authors can also consider qualifying the term "insufficient" by stating the main reason that lead to an insufficient rating (e.g., insufficient because of imprecision).

Implications for decisionmakers and recommendations for next steps may vary for evidence that is insufficient due to conflicting or heterogeneous studies, imprecise estimates of effect/association, poor applicability to population of interest, and/or high risk of bias studies. Approaches to supplementing evidence or recommendations for next steps may differ. In some cases, further exploration of heterogeneity could help to explore if there is an effect in a specific populations or settings. Authors should consider different recommendations for future research based on the different types of insufficient evidence.

\section{Discussion}

EPC systematic reviews examine the available evidence on one of the main factors that inform decisions - that is, the evidence for benefit or harm. However, decision makers must also consider a range of other factors, such as costs, values, preferences, and equity, and the relative weight of these factors may vary depending on the topic or the availability of evidence for benefit or harm. This report summarizes the findings of a workgroup from the EPC Program that sought to understand how systematic reviewers can further support decision making in the face of insufficient evidence for benefits or harms. We identified the various ways in which the term insufficient evidence has been used, defined, and understood in the literature; and what additional strategies can be performed by systematic reviewers to facilitate decisionmaking in the context of insufficient evidence.

We identified several strategies to augment decision making, such as summarizing indirect evidence, summarizing contextual and implementation evidence, modeling, and incorporating unpublished health system data in the review. One key challenge is that appropriate planning and budgeting of a review needs to be done early, alongside conversations with key informants about scope, whereas the determination of insufficient evidence may not be made until late in the review. As such, reviewers should consider options and strategies early and at each stage of the process: during the scoping or the review, protocol development, conducting of the review, and when reporting the findings. Even when insufficient evidence is identified later in the review process, some of the proposed approaches described to supplement the review may still be feasible with appropriate protocol amendments.

It is important to acknowledge the limitations of the evidence even with the implementation of these strategies, as well as our approach to identify them. These strategies do not "fix the problem" of insufficient evidence, but rather facilitate decision making in in the context of insufficient evidence. For example, adding unpublished health system data to a systematic review can improve precision of the estimates and may enhance applicability; however, such data are not peer reviewed and can suffer from various types of bias. We may have not included 
important strategies because our sample was limited to reports in which EPC investigators were involved, most of which are conducted for guideline groups or governmental agencies. Our evidence about the relative success of these strategies was also indirect and inferred from peer and public comments and not directly from end-users.

The examples, strategies, and recommendations in this document apply to the EPC Program and may not apply to other systematic reviewers. Although this project focuses on systematic reviews conducted following a traditional timeline, the approach can be applied to rapid reviews to address urgent clinical issues. The Severe Acute Respiratory Syndrome Coronavirus 2 (SARSCoV-2) pandemic serves as an ongoing example of a public health crisis requiring rapid reviews; these reviews may conclude insufficient evidence, yet provide information to support decision making. ${ }^{32}$

\section{Conclusion}

Systematic reviews commonly examine the evidence on benefits and harms of interventions but other factors are required for decisionmaking. When the strength of this evidence warrants insufficient rating, information on these factors can enhance the utility of systematic reviews for health systems and other stakeholders. We identified five potential strategies including broadening eligibility criteria to other study designs, summarizing indirect evidence, summarizing contextual and implementation evidence, modelling, and incorporating unpublished health system data in the review. 


\section{References}

1. Berkman ND, Lohr KN, Ansari M, et al. Grading the strength of a body of evidence when assessing health care interventions for the effective health care program of the Agency for Healthcare Research and Quality: an update. Methods Guide for Effectiveness and Comparative Effectiveness Reviews [Internet]. Rockville, MD: Agency for Healthcare Research and Quality (US); 2013.

2. Schünemann H, Brożek J, Guyatt G, et al. Handbook for grading the quality of evidence and the strength of recommendations using the GRADE approach GRADE Working Group. 2013.

3. Alonso-Coello P, Schünemann HJ, Moberg J, et al. GRADE Evidence to Decision (EtD) frameworks: a systematic and transparent approach to making well informed healthcare choices. 1: Introduction. BMJ. 2016;353:i2016. doi: https://dx.doi.org/10.1136/bmj.i2016. PMID: 27353417.

4. Christensen V, Floyd N, Anderson J. "It Would've Been Nice if They Interpreted the Data a Little Bit. It Didn't Really Say Much, and It Didn't Really Help Us.": A Qualitative Study of VA Health System Evidence Needs. Med Care. 2019;57(10 Suppl 3):S228. doi: https://dx.doi.org/10.1097/MLR.000000000 0001171. PMID: 31517792.

5. Bridges JF, Berger Z, Austin M, et al. Public Reporting of Cost Measures in Health. Agency for Healthcare Research and Quality Technical Brief. 2015. PMID: 25763451.

6. Leas BF, Tipton K, Bryant-Stephens T, et al. Characteristics of Existing Asthma SelfManagement Education Packages. Agency for Healthcare Research and Quality Technical Brief. 2020. PMID: 32369313.

7. Snyder D, Sullivan N, Margolis D, et al. Skin substitutes for treating chronic wounds. Agency for Healthcare Research and Quality Technical Brief. 2020. PMID: 32101391.
8. O’Neil M, McDonagh M, Hsu F, et al. Pharmacologic and Nonpharmacologic Treatments for Posttraumatic Stress Disorder: Groundwork for a Publicly Available Repository of Randomized Controlled Trial Data. Agency for Healthcare Research and Quality Technical Brief. 2019. PMID: 31145565.

9. Brasure M, Nelson VA, Scheiner S, et al. Treatment for Acute Pain: An Evidence Map. Agency for Healthcare Research and Quality Technical Brief. 2019. PMID: 31693321.

10. Ibe CA, Wilson LM, Brodine J, et al. Impact of Community Health Worker Certification on Workforce and Service Delivery for Asthma and Other Selected Chronic Diseases. Agency for Healthcare Research and Quality Technical Brief. 2020. PMID: 32255577.

11. Krist AH, Wolff TA, Jonas DE, et al. Update on the methods of the US Preventive Services Task Force: methods for understanding certainty and net benefit when making recommendations. Am J Prev Med. 2018;54(1):S11-S8. doi: https://dx.doi.org/10.1016/j.amepre.2017.09. 011. PMID: 29254521.

12. Hanquet G, Stefanoff P, Hellenbrand W, et al. Strong Public Health Recommendations from Weak Evidence? Lessons Learned in Developing Guidance on the Public Health Management of Meningococcal Disease. Biomed Res Int. 2015;2015:569235. doi: https://dx.doi.org/10.1155/2015/569235. PMID: 26693485.

13. Guirguis-Blake JM, Evans CV, Redmond N, et al. Screening for peripheral artery disease using the Ankle-Brachial Index: updated evidence report and systematic review for the US preventive services task force. JAMA. 2018;320(2):184-96. doi: https://dx.doi.org/10.1001/jama.2018.4250. PMID: 29998343. 
14. Jonas DE, Kahwati LC, Yun JD, et al. Screening for atrial fibrillation with electrocardiography: evidence report and systematic review for the US Preventive Services Task Force. JAMA. 2018;320(5):485-98. doi: https://dx.doi.org/10.1001/jama.2018.4190. PMID: 30088015.

15. RTI International-University of North Carolina Evidence-based Practice Center. Whole Exome Sequencing. Washington State Health Care Authority. 2019. doi: https://www.hca.wa.gov/assets/program/wh ole-exome-sequencing-final-rpt20191022.pdf.

16. Webber E, Thomas R, Lin JS. Implications of Multigene Panels for Hereditary Breast Cancer Risk Assessment. Not yet published.

17. Liem RI, Lanzkron S, D. Coates T, et al. American Society of Hematology 2019 guidelines for sickle cell disease: cardiopulmonary and kidney disease. Blood Adv. 2019;3(23):3867-97. doi: https://dx.doi.org/10.1182/bloodadvances.20 19000916. PMID: 31794601.

18. Shekelle PG, Sarkar U, Shojania K, et al. Patient safety in ambulatory settings. Agency for Healthcare Research and Quality Technical Brief. 2016. PMID: 27854399.

19. Gaynes B, Brown C, Lux LJ, et al. Relationship between use of quality measures and improved outcomes in serious mental illness. Agency for Healthcare Research and Quality Technical Brief. 2015. PMID: 25654159.

20. Adam GP, Di M, Cu-Uvin S, et al. Strategies for improving the lives of women aged 40 and above living with HIV/AIDS. Agency for Healthcare Research and Quality Technical Brief. 2016. PMID: 27929614.

21. Butler M, Ratner E, McCreedy E, et al. Decision aids for advance care planning: an overview of the state of the science. Agency for Healthcare Research and Quality (US). 2014; Technical Brief No. 14-EHC039-EF. PMID: 25069709.
22. Berkman ND, Lohr KN, Ansari M, et al. Grading the strength of a body of evidence when assessing health care interventions for the effective health care program of the Agency for Healthcare Research and Quality: an update. Methods Guide for Effectiveness and Comparative Effectiveness Reviews [Internet]. Agency for Healthcare Research and Quality (US); 2013.

23. Treadwell JR, Singh S, Talati R, et al. A framework for" best evidence" approaches in systematic reviews. Agency for Healthcare Research and Quality. 2011. PMID: 21834173.

24. Norris S, Atkins D, Bruening W, et al. Selecting observational studies for comparing medical interventions. Methods guide for effectiveness and comparative effectiveness reviews [Internet]. Agency for Healthcare Research and Quality (US); 2010.

25. Brandow AM, Carroll CP, Creary S, et al. American Society of Hematology 2020 guidelines for sickle cell disease: management of acute and chronic pain. Blood Adv. 2020;4(12):2656-701. doi: https://dx.doi.org/10.1182/bloodadvances.20 20001851. PMID: 32559294.

26. Wang Z, Whiteside SP, Sim L, et al. Comparative effectiveness and safety of cognitive behavioral therapy and pharmacotherapy for childhood anxiety disorders: a systematic review and meta-analysis. JAMA Pediatr. 2017;171(11):1049-56. doi: https://dx.doi.org/10.1001/jamapediatrics.20 17.3036. PMID: 28859190.

27. Morrow AS, Whiteside SP, Sim LA, et al. Developing tools to enhance the use of systematic reviews for clinical care in health systems. BMJ Evid Based Med. 2018;23(6):206-9. doi: https://dx.doi.org/10.1136/bmjebm-2018110995. PMID: 30194075.

28. Colvin CJ, de Heer J, Winterton L, et al. A systematic review of qualitative evidence on barriers and facilitators to the implementation of task-shifting in midwifery services. Midwifery. 2013;29(10):1211-21. doi: https://dx.doi.org/10.1016/j.midw.2013.05.0 01. PMID: 23769757. 
29. Writing Committee of the Breast Cancer

Working Group, Cancer Intervention and

Surveillance Modeling Network (CISNET),

Breast Cancer Surveillance Consortium

(BCSC). Collaborative Modeling of U.S.

Breast Cancer Screening Strategies. Agency

for Healthcare Research and Quality (US).

2015;Report No. 14-05201-EF-4.

30. Lin JS, Murad MH, Leas B, et al. Integrating Health System Data With Systematic

Reviews: A Framework for When and How Unpublished Health System Data Can Be Used With Systematic Reviews To Support Health System Decision Making. Agency for Healthcare Research and Quality (US). 2020;Report No.: 19(20)-EHC023-EF. doi: https://doi.org/10.23970/AHRQEPCMETH QUALIMPRINTEGRATING. PMID: 32271513 .

31. Morales-Valero S, Brinjikji W, Murad MH, et al. Endovascular treatment of internal carotid artery bifurcation aneurysms: a single-center experience and a systematic review and meta-analysis. AJNR Am J Neuroradiol. 2014;35(10):1948-53. doi: https://dx.doi.org/10.3174/ajnr.A3992. PMID: 24904050.

32. Chou R, Dana T, Jungbauer R, et al. Masks for prevention of respiratory virus infections, including SARS-CoV-2, in health care and community settings: a living rapid review. Ann Intern Med. 2020. doi: https://dx.doi.org/10.7326/M20-3213. PMID: 32579379. 


\section{Abbreviations and Acronyms}

$\begin{array}{ll}\text { AHRQ } & \text { Agency for Healthcare Research and Quality } \\ \text { EPC } & \text { Evidence-based Practice Center } \\ \text { GRADE } & \text { Grading of Recommendations Assessment, Development and Evaluation } \\ \text { KI } & \text { Key Informant } \\ \text { SARS-CoV-2 } & \text { Severe Acute Respiratory Syndrome Coronavirus 2 } \\ \text { SoE } & \text { Strength of evidence } \\ \text { SRC } & \text { Scientific Resource Center } \\ \text { USPSTF } & \text { United States Preventive Services Task Force }\end{array}$




\section{Appendix A. Search Strategies}

\section{Ovid MEDLINE(R) ALL 1946 to September 25, 2019}

Date searched: September 27, 2019

Searched by: Robin Paynter, MLIS

\begin{tabular}{|l|l|r|}
\hline$\#$ & Searches & Results \\
\hline 1 & $\begin{array}{l}((\text { absence or equivocal or incomplete or insufficient or minimal or missing or "not } \\
\text { enough" or uncertain*) adj2 (effectiveness or evidence or research)).ti. }\end{array}$ & 894 \\
\hline 2 & $\begin{array}{l}((\text { absence or equivocal or incomplete or insufficient or minimal or missing or } \\
\text { uncertain*) adj2 (effectiveness or evidence or research)).ti,ab. or "Evidence to } \\
\text { decision".kf. or ((utili?ation or weak) adj2 evidence).ti. }\end{array}$ & 16096 \\
\hline 3 & $\begin{array}{l}\text { Decision Making/ or Delivery of Health Care/ or Health Policy/ or Health Services } \\
\text { Research/ or Policy Making/ or Uncertainty/ }\end{array}$ & 282423 \\
\hline 4 & $\begin{array}{l}(((\text { evidence-based or evidence-informed) adj2 (policy* or policies)) or decision* or } \\
((\text { health* or hospital) adj2 (system or systems) }) \text { or policies or policy*).ti,kf. }\end{array}$ & 164219 \\
\hline 5 & or/3-4 & 385350 \\
\hline 6 & \begin{tabular}{l} 
and/2,5 \\
\hline 7
\end{tabular} & $\begin{array}{l}\text { or/1,6 } \\
\text { limit } 7 \text { to english language }\end{array}$ \\
\hline
\end{tabular}




\section{Appendix B. Literature Review References}

1. Altman D, Bland JM. Confidence intervals illuminate absence of evidence. Bmj. 2004 Apr 24;328(7446):1016-7. PMID: 15105337.

2. Robinson KA, Akinyede O, Dutta T, et al. Framework for Determining Research Gaps During Systematic Review: Evaluation. Agency for Healthcare Research and Quality. 2013;Report No.: 13-EHC019-EF. PMID: 23487868.

3. Altman DG, Bland JM. Absence of evidence is not evidence of absence. Bmj. 1995 Aug 19;311(7003):485. PMID: 7647644.

4. Ezzo J, Bausell B, Moerman DE, et al. Reviewing the reviews. How strong is the evidence? How clear are the conclusions? Int $\mathbf{J}$ Technol Assess Health Care. 2001;17(4):457-66. PMID: 11758290.

5. Bilcke J, Beutels P, Brisson M, et al. Accounting for methodological, structural, and parameter uncertainty in decision-analytic models: a practical guide. Med Decis Making. 2011 Jul-Aug;31(4):675-92. doi: https://dx.doi.org/10.1177/0272989X114092 40. PMID: 21653805.

6. Benmarhnia T, Huang JY, Jones CM. Lost in Translation: Piloting a Novel Framework to Assess the Challenges in Translating Scientific Uncertainty From Empirical Findings to WHO Policy Statements. Int. 2017 Mar 01;6(11):649-60. doi: https://dx.doi.org/10.15171/ijhpm.2017.28. PMID: 29179291.

7. Harris RP, Helfand M, Woolf SH, et al. Current methods of the US Preventive Services Task Force: a review of the process. Am J Prev Med. 2001 Apr;20(3 Suppl):21-35. PMID: 11306229.

8. Alvaro C, Lyons RF, Warner G, et al. Conservation of resources theory and research use in health systems. Implement Sci. 2010 Oct 20;5:79. doi: https://dx.doi.org/10.1186/1748-5908-5-79. PMID: 20961445.
9. Anonymous. Public health policy-making in the presence of incomplete evidence. Am J Public Health. 1990 Jun;80(6):746-50. PMID: 2343972.

10. El-Jardali F, Lavis JN, Ataya N, et al. Use of health systems and policy research evidence in the health policymaking in eastern Mediterranean countries: views and practices of researchers. Implement Sci. 2012 Jan 11;7:2. doi: https://dx.doi.org/10.1186/1748-5908-7-2. PMID: 22236561.

11. Levallois P, Gauvin D. Management in the context of incomplete evidence. Can J Public Health. 1995 May-Jun;86(3):169. PMID: 7671200.

12. Levin L, Goeree R, Levine M, et al. Coverage with evidence development: the Ontario experience. Int J Technol Assess Health Care. 2011 Apr;27(2):159-68. doi: https://dx.doi.org/10.1017/S0266462311000 018. PMID: 21473814.

13. Lexchin J. Coverage with evidence development for pharmaceuticals: a policy in evolution? Int J Health Serv. 2011;41(2):337-54. PMID: 21563627.

14. Hageman MG, Guitton TG, Ring D, et al. How surgeons make decisions when the evidence is inconclusive. J Hand Surg [Am]. 2013 Jun;38(6):1202-8. doi: https://dx.doi.org/10.1016/j.jhsa.2013.02.03 2. PMID: 23647639.

15. Vujcich D, Rayner M, Allender S, et al. When There Is Not Enough Evidence and When Evidence Is Not Enough: An Australian Indigenous Smoking Policy Study. Front. 2016;4:228. PMID: 27812523.

16. Weed DL. Precaution, prevention, and public health ethics. J Med Philos. 2004 Jun;29(3):313-32. PMID: 15512975.

17. Wilson LM, Robinson KA. Understanding and interpreting guideline recommendations made with insufficient evidence. Paediatr Respir Rev. 2015 Jan;16(1):49-50. doi: https://dx.doi.org/10.1016/j.prrv.2014.09.00 2. PMID: 25263478. 
18. Li SA, Alexander PE, Reljic T, et al. Evidence to Decision framework provides a structured "roadmap" for making GRADE guidelines recommendations. J Clin Epidemiol. 2018 12;104:103-12. doi: https://dx.doi.org/10.1016/j.jclinepi.2018.09. 007. PMID: 30253221.

19. D'Souza BJ, Parkhurst JO. When "Good Evidence" Is Not Enough: A Case of Global Malaria Policy Development. Global chall. 2018 Sep;2(9):1700077. doi: https://dx.doi.org/10.1002/gch2.201700077. PMID: 31565347.

20. Djulbegovic B, Trikalinos TA, Roback J, et al. Impact of quality of evidence on the strength of recommendations: an empirical study. BMC Health Serv Res. 2009 Jul 21;9:120. doi: https://dx.doi.org/10.1186/1472-6963-9120. PMID: 19622148.

21. Longworth L, Sculpher MJ, Bojke L, et al. Bridging the gap between methods research and the needs of policy makers: a review of the research priorities of the National Institute for Health and Clinical Excellence. Int J Technol Assess Health Care. 2011 Apr;27(2):180-7. doi: https://dx.doi.org/10.1017/S0266462311000 043. PMID: 21447260.

22. McCormack L, Sheridan S, Lewis M, et al. Communication and dissemination strategies to facilitate the use of health-related evidence. Evid rep/technol assess. 2013 Nov(213):1-520. PMID: 24423078.

23. Mohindra RK. NICE should not intervene where there is equipoise by virtue of insufficient evidence. Heart. 2010 Aug;96(16):1333; author reply doi: https://dx.doi.org/10.1136/hrt.2010.200758. PMID: 20659955.

24. Melnyk BM, Grossman DC, Chou R, et al. USPSTF perspective on evidence-based preventive recommendations for children. Pediatrics. 2012 Aug;130(2):e399-407. PMID: 22753558.

25. Politi MC, Clark MA, Ombao H, et al. Communicating uncertainty can lead to less decision satisfaction: a necessary cost of involving patients in shared decision making? Health Expect. 2011 Mar;14(1):8491. doi: https://dx.doi.org/10.1111/j.13697625.2010.00626.x. PMID: 20860780.
26. Politi MC, Clayman ML, Fagerlin A, et al. Insights from a conference on implementing comparative effectiveness research through shared decision-making. J. 2013 Jan;2(1):23-32. PMID: 23430243.

27. Richter Sundberg L, Garvare R, Nystrom ME. Reaching beyond the review of research evidence: a qualitative study of decision making during the development of clinical practice guidelines for disease prevention in healthcare. BMC Health Serv Res. 201705 11;17(1):344. doi: https://dx.doi.org/10.1186/s12913-0172277-1. PMID: 28490325.

28. Schriger DL. Management of the young febrile child. Clinical guidelines in the setting of incomplete evidence. Pediatrics. 1997 Jul;100(1):136. PMID: 9200372.

29. Steel N, Abdelhamid A, Stokes T, et al. A review of clinical practice guidelines found that they were often based on evidence of uncertain relevance to primary care patients. J Clin Epidemiol. 2014 Nov;67(11):1251-7. doi:

https://dx.doi.org/10.1016/j.jclinepi.2014.05. 020. PMID: 25199598.

30. Mohindra RK. A case of insufficient evidence equipoise: the NICE guidance on antibiotic prophylaxis for the prevention of infective endocarditis. J Med Ethics. 2010 Sep;36(9):567-70. doi: https://dx.doi.org/10.1136/jme.2010.036848. PMID: 20663759.

31. Nicod E, Berg Brigham K, Durand-Zaleski I, et al. Dealing with Uncertainty and Accounting for Social Value Judgments in Assessments of Orphan Drugs: Evidence from Four European Countries. Value Health. 2017 Jul - Aug;20(7):919-26. doi: https://dx.doi.org/10.1016/j.jval.2017.03.005 . PMID: 28712621.

32. Oxman AD, Lavis JN, Fretheim A, et al. SUPPORT Tools for evidence-informed health Policymaking (STP) 17: Dealing with insufficient research evidence. Health Res Policy Syst. 2009 Dec 16;7 Suppl 1:S17. doi: https://dx.doi.org/10.1186/1478-4505-7S1-S17. PMID: 20018107. 
33. Petitti DB, Teutsch SM, Barton MB, et al. Update on the methods of the U.S. Preventive Services Task Force: insufficient evidence. Ann Intern Med. 2009 Feb 03;150(3):199205. PMID: 19189910.

34. Uhlig K. What should a guideline panel do when evidence is inconclusive? The case of treatments for CKD-mineral and bone disorder (CKD-MBD). Am J Kidney Dis. 2011 Dec;58(6):872-5. doi: https://dx.doi.org/10.1053/j.ajkd.2011.08.00 1. PMID: 21890254.

35. Christensen V, Floyd N, Anderson J. "It Would've Been Nice if They Interpreted the Data a Little Bit. It Didn't Really Say Much, and It Didn't Really Help Us.": A Qualitative Study of VA Health System Evidence Needs. Med Care. 2019 Oct;57 Suppl 10 Suppl 3:S228-S32. doi: https://dx.doi.org/10.1097/MLR.000000000 0001171. PMID: 31517792.

36. Helfand M. Incorporating information about costeffectiveness into evidence-based decisionmaking: the evidence-based practice center (EPC) model. Med Care. 2005 Jul;43(7 Suppl):33-43. PMID: 16056007.

37. Jenicek M. Evidence-based medicine: fifteen years later. Golem the good, the bad, and the ugly in need of a review? Med Sci Monit. 2006 Nov;12(11):RA241-51. PMID: 17072278.

38. LeFevre M. How helpful are task force statements about "insufficient evidence"? Medscape J Med. 2008 Mar 31;10(3):77. PMID: 18449375.
39. Baxter K, Field A, Terry SF. "Insufficient evidence" isn't sufficient anymore. Genet Test Mol Biomarkers. 2011 Mar;15(3):1156. doi: https://dx.doi.org/10.1089/gtmb.2011.1517. PMID: 21352088.

40. Chalmers I. Systematic reviews: insufficient evidence on which to base medicine. Br J Obstet Gynaecol. 1998 Nov;105(11):1235-6. PMID: 9853778.

41. Frame PS. Preventive care for the elderly: getting by in the absence of evidence. Am Fam Physician. 1999 Apr 01;59(7):1747-8, 50. PMID: 10208697.

42. Hutton J, Trueman P, Henshall C. Coverage with evidence development: an examination of conceptual and policy issues. Int $\mathrm{J}$ Technol Assess Health Care. 2007;23(4):425-32. PMID: 17937829.

43. Consonni D, Bertazzi PA. Health significance and statistical uncertainty. The value of Pvalue. Med Lav. 201710 27;108(5):327-31. doi:

https://dx.doi.org/10.23749/mdl.v108i5.660 3. PMID: 29084124 .

44. Hanquet G, Stefanoff P, Hellenbrand W, et al. Strong Public Health Recommendations from Weak Evidence? Lessons Learned in Developing Guidance on the Public Health Management of Meningococcal Disease. Biomed Res Int. 2015;2015:569235. doi: https://dx.doi.org/10.1155/2015/569235. PMID: 26693485. 


\section{Appendix C. Review of Systematic Reviews}

Table C-1. List of reports included in the review of systematic reviews

\begin{tabular}{|c|c|c|c|c|}
\hline $\begin{array}{l}\text { Report Title } \\
\text { (43 articles) }\end{array}$ & Key Question & End-user & Decisional Dilemma & $\begin{array}{l}\text { Reason for Insufficient } \\
\text { Evidence Rating }\end{array}$ \\
\hline $\begin{array}{l}\text { Screening to Prevent } \\
\text { Osteoporotic Fractures: } \\
\text { An Evidence Review for } \\
\text { the U.S. Preventive } \\
\text { Services Task Force }^{1}\end{array}$ & $\begin{array}{l}\text { What Are the Harms } \\
\text { Associated with } \\
\text { Pharmacotherapy? }\end{array}$ & $\begin{array}{l}\text { United States Preventive } \\
\text { Services Task Force } \\
\text { (USPSTF) }\end{array}$ & $\begin{array}{l}\text { Whether or not to recommend } \\
\text { screening to prevent osteoporotic } \\
\text { fractures. The screening decision } \\
\text { requires understanding whether } \\
\text { screening is accurate in identifying } \\
\text { those at risk, and then in } \\
\text { identifying whether treatment of } \\
\text { those at risk is safe and effective } \\
\text { compared to no treatment. }\end{array}$ & No eligible evidence \\
\hline $\begin{array}{l}\text { Speech and Language } \\
\text { Delay and Disorders in } \\
\text { Children Age } 5 \text { and } \\
\text { Younger: Screening }{ }^{2}\end{array}$ & $\begin{array}{l}\text { Do Interventions for } \\
\text { Speech and Language } \\
\text { Delays or Disorders } \\
\text { Improve Speech and } \\
\text { Language Outcomes? }\end{array}$ & USPSTF & $\begin{array}{l}\text { Whether to recommend screening } \\
\text { of speech and language disorders. } \\
\text { To assess whether screening for } \\
\text { speech and language delays or } \\
\text { disorders in young children, } \\
\text { required determining whether } \\
\text { screening tests were accurate and } \\
\text { whether treatments for those } \\
\text { identified with disorders are } \\
\text { beneficial and without any harm. }\end{array}$ & $\begin{array}{l}\text { Inadequate evidence due to } \\
\text { inconsistent findings on } \\
\text { outcomes, studies conducted } \\
\text { in high risk populations, } \\
\text { children's speech and } \\
\text { language delays had not } \\
\text { been detected by screening } \\
\text { but rather due to parental or } \\
\text { teacher concerns }\end{array}$ \\
\hline $\begin{array}{l}\text { Screening for } \\
\text { Cardiovascular Disease } \\
\text { Risk } 1 \text { With Resting or } \\
\text { Exercise } \\
\text { Electrocardiography: } \\
\text { Evidence Report and } \\
\text { Systematic Review for } \\
\text { the US Preventive } \\
\text { Services Task Force }\end{array}$ & $\begin{array}{l}\text { Does the addition of } \\
\text { screening with resting or } \\
\text { exercise ECG to traditional } \\
\text { CVD risk factor } \\
\text { assessment accurately } \\
\text { reclassify persons into } \\
\text { different risk groups (eg, } \\
\text { high-, intermediate-, and } \\
\text { low-risk groups) or improve } \\
\text { measures of calibration } \\
\text { and discrimination? }\end{array}$ & USPSTF & $\begin{array}{l}\text { Recommend additional screening } \\
\text { with ECG or EGC exercise stress }\end{array}$ & $\begin{array}{l}\text { For calibration - } 4 \text { studies but } \\
\text { all have different metrics for } \\
\text { calibration. For NRI - only } \\
\text { one study }\end{array}$ \\
\hline $\begin{array}{l}\text { Screening for Atrial } \\
\text { Fibrillation With } \\
\text { Electrocardiography: An } \\
\text { Evidence Review for the } \\
\text { U.S. Preventive Services } \\
\text { Task Force }\end{array}$ & $\begin{array}{l}\text { KQ3. What Are the Harms } \\
\text { of Screening for AF With } \\
\text { ECG in Older Adults? }\end{array}$ & USPSTF & To screen or not to screen & No eligible evidence \\
\hline
\end{tabular}




\begin{tabular}{|c|c|c|c|c|}
\hline $\begin{array}{l}\text { Report Title } \\
\text { (43 articles) }\end{array}$ & Key Question & End-user & Decisional Dilemma & $\begin{array}{l}\text { Reason for Insufficient } \\
\text { Evidence Rating }\end{array}$ \\
\hline $\begin{array}{l}\text { Whole Exome } \\
\text { Sequencing: Final } \\
\text { Evidence Report }^{5}\end{array}$ & $\begin{array}{l}\text { 3 KQs had insufficient } \\
\text { (GRADE equivalent of } \\
\text { VERY LOW): } \\
\text { 1. What is the clinical utility } \\
\text { of WES (i.e., changes to } \\
\text { medications, further } \\
\text { diagnostic testing, other } \\
\text { treatment/management)? } \\
\text { 2. What is the impact on } \\
\text { health outcomes from use } \\
\text { of WES? } \\
\text { 3. What is the cost- } \\
\text { effectiveness of WES } \\
\text { testing (compared to no } \\
\text { WES testing)? }\end{array}$ & $\begin{array}{l}\text { Washington State's } \\
\text { independent Health } \\
\text { Technology Clinical } \\
\text { Committee }\end{array}$ & $\begin{array}{l}\text { Whether to cover WES as included } \\
\text { benefit for state-purchased health } \\
\text { care (i.e., Medicaid, Dept of } \\
\text { Corrections, Workers Comp, and } \\
\text { State Employee's Health Plan) in } \\
\text { the absence of sufficient evidence. }\end{array}$ & $\begin{array}{l}\text { Bodies of evidence for the } \\
\text { KQ noted here had serious } \\
\text { study limitations (risk of bias), } \\
\text { serious inconsistency, and } \\
\text { serious imprecision; this } \\
\text { resulted in VERY LOW } \\
\text { GRADE certainty ratings } \\
\text { (equivalent to AHRQ } \\
\text { Insufficient). }\end{array}$ \\
\hline $\begin{array}{l}\text { Screening for Unhealthy } \\
\text { Drug Use in Primary } \\
\text { Care in Adolescents and } \\
\text { Adults, Including } \\
\text { Pregnant Persons: } \\
\text { Updated Systematic } \\
\text { Review for the US } \\
\text { Preventive Services Task } \\
\text { Force }^{6}\end{array}$ & $\begin{array}{l}\text { KQ1: Does primary care } \\
\text { screening for drug use in } \\
\text { adolescents and adults } \\
\text { reduce drug use or } \\
\text { improve other risky } \\
\text { behaviors or reduce } \\
\text { morbidity or mortality and } \\
\text { improve other health, } \\
\text { social, or legal outcomes? } \\
\text { KQ3: What are the harms } \\
\text { of primary care screening } \\
\text { for drug use in adolescents } \\
\text { and adults?" }\end{array}$ & USPSTF & $\begin{array}{l}\text { Whether to recommend drug } \\
\text { screening or not }\end{array}$ & No eligible evidence \\
\hline $\begin{array}{l}\text { Implications of Multigene } \\
\text { Panels for Hereditary } \\
\text { Breast Cancer (HBOC) } \\
\text { Risk Assessment }^{7}\end{array}$ & $\begin{array}{l}\text { What is the accuracy of } \\
\text { familial risk assessment } \\
\text { tools for hereditary breast } \\
\text { and ovarian cancer when } \\
\text { performed by a non- } \\
\text { specialist in genetics in a } \\
\text { clinical setting? Have any } \\
\text { of these risk assessment } \\
\text { tools been validated } \\
\text { against multigene panels? } \\
\text { What are the optimal ages } \\
\text { and intervals for risk } \\
\text { assessment? }\end{array}$ & $\begin{array}{l}\text { Kaiser Permanente Care } \\
\text { Management Institute (CMI) }\end{array}$ & $\begin{array}{l}\text { Mismatch between } \\
\text { recommendations (BRCA testing) } \\
\text { and clinical care (multigene panel } \\
\text { testings) }\end{array}$ & $\begin{array}{l}\text { No eligible studies compared } \\
\text { with multigene panel testing } \\
\text { (all were compared with } \\
\text { BRCA testing only) }\end{array}$ \\
\hline
\end{tabular}




\begin{tabular}{|c|c|c|c|c|}
\hline $\begin{array}{l}\text { Report Title } \\
\text { (43 articles) }\end{array}$ & Key Question & End-user & Decisional Dilemma & $\begin{array}{l}\text { Reason for Insufficient } \\
\text { Evidence Rating }\end{array}$ \\
\hline $\begin{array}{l}\text { Screening for Peripheral } \\
\text { Artery Disease Using the } \\
\text { Ankle-Brachial Index: An } \\
\text { Updated Systematic } \\
\text { Review for the U.S. } \\
\text { Preventive Services Task } \\
\text { Force }^{8}\end{array}$ & $\begin{array}{l}\text { KQ2 What is the diagnostic } \\
\text { accuracy of the ABI as a } \\
\text { screening test for PAD in } \\
\text { generally asymptomatic } \\
\text { adults? }\end{array}$ & USPSTF & $\begin{array}{l}1 \text { older fair-quality study in a } \\
\text { restricted population shows poor } \\
\text { accuracy. How generalizable is } \\
\text { this study to other ages and in the } \\
\text { contemporary US? }\end{array}$ & $\begin{array}{l}1 \text { small study of fair quality } \\
\text { restricted to a population of } \\
\text { older adults (age } 70 \text { ) in } \\
\text { Sweden showing very low } \\
\text { sensitivity ( } 95 \% \mathrm{Cl}, 7 \% \text { to } \\
34 \%)\end{array}$ \\
\hline $\begin{array}{l}\text { Periodic Screening with } \\
\text { the Pelvic Examination }\end{array}$ & $\begin{array}{l}\text { KQ1: What is the direct } \\
\text { evidence for the } \\
\text { effectiveness of screening } \\
\text { with the pelvic examination } \\
\text { in: } \\
\text { Reducing all-cause } \\
\text { mortality, reducing cancer- } \\
\text { and disease-specific } \\
\text { morbidity and mortality, } \\
\text { improving quality of life } \\
\text { KQ2: What are the test } \\
\text { performance } \\
\text { characteristics of the pelvic } \\
\text { examination (i.e., } \\
\text { sensitivity, specificity, } \\
\text { positive and negative } \\
\text { predictive values) in } \\
\text { screening for } \\
\text { gynecological cancers and } \\
\text { other gynecological } \\
\text { conditions? } \\
\text { KQ3: What are the } \\
\text { adverse effects of } \\
\text { screening with the pelvic } \\
\text { examination? }\end{array}$ & USPSTF & $\begin{array}{l}\text { Very few studies in appropriate } \\
\text { asymptomatic populations seen in } \\
\text { primary care. Limited evidence for } \\
\text { evaluating detection rates for few } \\
\text { conditions. No direct evidence on } \\
\text { effectiveness, little evidence on } \\
\text { harms applicable to primary care } \\
\text { populations. }\end{array}$ & $\begin{array}{l}\text { Insufficient evidence for } \\
\text { determining test performance } \\
\text { of screening test - few } \\
\text { studies, not very applicable } \\
\text { evidence. No studies with } \\
\text { direct evidence and few } \\
\text { studies with limited } \\
\text { applicability on harms. }\end{array}$ \\
\hline
\end{tabular}




\begin{tabular}{|c|c|c|c|c|}
\hline $\begin{array}{l}\text { Report Title } \\
\text { (43 articles) }\end{array}$ & Key Question & End-user & Decisional Dilemma & $\begin{array}{l}\text { Reason for Insufficient } \\
\text { Evidence Rating }\end{array}$ \\
\hline $\begin{array}{l}\text { Screening for Pancreatic } \\
\text { Cancer: Updated } \\
\text { Evidence Report and } \\
\text { Systematic Review for } \\
\text { the US Preventive } \\
\text { Services Task Force }^{10}\end{array}$ & $\begin{array}{l}\text { KQ1. Does screening for } \\
\text { pancreatic } \\
\text { adenocarcinoma improve } \\
\text { cancer morbidity or } \\
\text { mortality or all-cause } \\
\text { mortality?; KQ4. Does } \\
\text { treatment of screen- } \\
\text { detected or asymptomatic } \\
\text { pancreatic } \\
\text { adenocarcinoma improve } \\
\text { cancer mortality, all-cause } \\
\text { mortality, or quality of life? }\end{array}$ & USPSTF & $\begin{array}{l}\text { Whether or not to recommend } \\
\text { screening for pancreatic cancer in } \\
\text { asymptomatic people }\end{array}$ & No eligible evidence \\
\hline $\begin{array}{l}\text { Behavioral Counseling } \\
\text { for Skin Cancer } \\
\text { Prevention: A } \\
\text { Systematic Evidence } \\
\text { Review for the U.S. } \\
\text { Preventive Services Task } \\
\text { Force }^{11}\end{array}$ & $\begin{array}{l}\text { KQ4. What is the } \\
\text { association between skin } \\
\text { self-examination and skin } \\
\text { cancer outcomes } \\
\text { (melanoma, squamous } \\
\text { cell, or basal cell } \\
\text { carcinoma incidence, } \\
\text { morbidity, or mortality)?; } \\
\text { KQ5. What are the harms } \\
\text { of skin self-examination? }\end{array}$ & USPSTF & $\begin{array}{l}\text { Whether or not to recommend } \\
\text { behavioral counseling for skin } \\
\text { cancer prevention in asymptomatic } \\
\text { people }\end{array}$ & No eligible evidence \\
\hline $\begin{array}{l}\text { Screening for } \\
\text { Adolescent Idiopathic } \\
\text { Scoliosis: A Systematic } \\
\text { Evidence Review for the } \\
\text { U.S. Preventive Services } \\
\text { Task Force }{ }^{12}\end{array}$ & $\begin{array}{l}\text { KQ1. Does screening for } \\
\text { adolescent idiopathic } \\
\text { scoliosis improve: a) health } \\
\text { outcomes, and b) the } \\
\text { degree of abnormal spinal } \\
\text { curvature in childhood or } \\
\text { adulthood?; KQ5. What } \\
\text { are the harms of screening } \\
\text { for adolescent idiopathic } \\
\text { scoliosis? }\end{array}$ & USPSTF & $\begin{array}{l}\text { Whether or not to recommend } \\
\text { screening for idiopathic scoliosis in } \\
\text { adolescents }\end{array}$ & No eligible evidence \\
\hline $\begin{array}{l}\text { Comparative } \\
\text { effectiveness and safety } \\
\text { of cognitive behavioral } \\
\text { therapy and } \\
\text { pharmacotherapy for } \\
\text { childhood anxiety } \\
\text { disorders: a systematic } \\
\text { review and meta- } \\
\text { analysis }{ }^{13}\end{array}$ & $\begin{array}{l}\text { Are SNRIs drug class } \\
\text { effective in reducing } \\
\text { anxiety symptoms as } \\
\text { reported by the patient? }\end{array}$ & $\begin{array}{l}\text { None, the question was } \\
\text { nominated by a researcher }\end{array}$ & $\begin{array}{l}\text { Whether to use medications in } \\
\text { children with anxiety, particularly } \\
\text { younger children }\end{array}$ & $\begin{array}{l}\text { Severe imprecision (wide } \\
\mathrm{Cls} \text { ) and high heterogeneity }\end{array}$ \\
\hline
\end{tabular}




\begin{tabular}{|c|c|c|c|c|}
\hline $\begin{array}{l}\text { Report Title } \\
\text { (43 articles) }\end{array}$ & Key Question & End-user & Decisional Dilemma & $\begin{array}{l}\text { Reason for Insufficient } \\
\text { Evidence Rating }\end{array}$ \\
\hline $\begin{array}{l}\text { The Clinical Utility of } \\
\text { Fractional Exhaled Nitric } \\
\text { Oxide (FeNO) in Asthma } \\
\text { Management }^{14}\end{array}$ & $\begin{array}{l}\text { In children ages } 0-4 \text { years } \\
\text { with recurrent wheezing, } \\
\text { can FeNO predict the } \\
\text { future development of } \\
\text { asthma? }\end{array}$ & $\begin{array}{l}\text { National Heart, Lung, and } \\
\text { Blood Institute (NHLBI) }\end{array}$ & $\begin{array}{l}\text { Should we do the test on very } \\
\text { young children who present with } \\
\text { wheezing to predict whether they } \\
\text { will develop asthma after the age } \\
\text { of } 5 \text { years? }\end{array}$ & $\begin{array}{l}\text { Contradictory results of } \\
\text { studies that were } \\
\text { summarized narratively } \\
\text { (could not be combined in } \\
\text { meta-analysis) }\end{array}$ \\
\hline $\begin{array}{l}\text { Pharmacologic and } \\
\text { Nonpharmacologic } \\
\text { Therapies in Adult } \\
\text { Patients with } \\
\text { Exacerbation of COPD }{ }^{15}\end{array}$ & $\begin{array}{l}\text { In adult patients with acute } \\
\text { exacerbation of COPD, } \\
\text { what are the benefits and } \\
\text { harms of systemic } \\
\text { corticosteroids and } \\
\text { antibiotics compared with } \\
\text { placebo or standard care? }\end{array}$ & $\begin{array}{l}\text { American Academy of Family } \\
\text { Physicians }\end{array}$ & $\begin{array}{l}\text { Using antibiotics for acute COPD } \\
\text { exacerbations }\end{array}$ & $\begin{array}{l}\text { Severe imprecision (wide } \\
\mathrm{Cls)} \text { and risk of bias }\end{array}$ \\
\hline $\begin{array}{l}\text { American Society of } \\
\text { Hematology } 2019 \\
\text { guidelines for sickle cell } \\
\text { disease: } \\
\text { cardiopulmonary and } \\
\text { kidney disease }^{16}\end{array}$ & $\begin{array}{l}\text { Should screening for } \\
\text { abnormal pulmonary } \\
\text { function vs no screening } \\
\text { be performed for } \\
\text { asymptomatic patients with } \\
\text { SCD? }\end{array}$ & $\begin{array}{l}\text { American Society of } \\
\text { Hematology }\end{array}$ & $\begin{array}{l}\text { Whether to recommend routine } \\
\text { screening with PFTs in patients } \\
\text { with sickle cell disease }\end{array}$ & $\begin{array}{l}\text { Observational studies with } \\
\text { increased risk of bias }\end{array}$ \\
\hline $\begin{array}{l}\text { Pharmacological } \\
\text { Management of } \\
\text { Osteoporosis in } \\
\text { Postmenopausal } \\
\text { Women: An Endocrine } \\
\text { Society }{ }^{*} \text { Clinical Practice } \\
\text { Guideline }^{17}\end{array}$ & $\begin{array}{l}\text { In postmenopausal women } \\
\text { at high risk of fracture with } \\
\text { osteoporosis, should } \\
\text { calcitonin be used to } \\
\text { reduce the risk of } \\
\text { fractures? }\end{array}$ & Endocrine Society & $\begin{array}{l}\text { Using a likely less effective } \\
\text { medicine }\end{array}$ & $\begin{array}{l}\text { Imprecise estimates for hip } \\
\text { and nonvertebral fracture } \\
\text { outcomes, high risk of bias in } \\
\text { trials of all three outcomes }\end{array}$ \\
\hline $\begin{array}{l}2018 \text { American College } \\
\text { of } \\
\text { Rheumatology/National } \\
\text { Psoriasis Foundation } \\
\text { Guideline for the } \\
\text { Treatment of Psoriatic } \\
\text { Arthritis }{ }^{18}\end{array}$ & $\begin{array}{l}\text { In adult patients with active } \\
\text { Psoriatic Arthritis, what are } \\
\text { the benefits and harms of } \\
\text { exercise compared to no } \\
\text { exercise? }\end{array}$ & $\begin{array}{l}\text { American College of } \\
\text { Rheumatology }\end{array}$ & $\begin{array}{l}\text { Whether to recommend exercise in } \\
\text { patients with psoriatic arthritis }\end{array}$ & No eligible evidence \\
\hline $\begin{array}{l}\text { Testing for Clostridium } \\
\text { Difficile in Oncology } \\
\text { Patients }^{19}\end{array}$ & $\begin{array}{l}\text { In inpatient oncology adult } \\
\text { patients, which tests for C. } \\
\text { diff (ELISA and/or PCR) } \\
\text { should be used for } \\
\text { diagnosis? }\end{array}$ & $\begin{array}{l}\text { University of Pennsylvania } \\
\text { Health System executives } \\
\text { and clinicians }\end{array}$ & $\begin{array}{l}\text { Inability to standardize accurate } \\
\text { diagnosis of } C \text { diff in oncology } \\
\text { patients, in an effort to reduce } \\
\text { false positive tests and over- } \\
\text { treatment }\end{array}$ & No eligible evidence \\
\hline
\end{tabular}




\begin{tabular}{|c|c|c|c|c|}
\hline $\begin{array}{l}\text { Report Title } \\
\text { (43 articles) }\end{array}$ & Key Question & End-user & Decisional Dilemma & $\begin{array}{l}\text { Reason for Insufficient } \\
\text { Evidence Rating }\end{array}$ \\
\hline $\begin{array}{l}\text { Oral antibiotics for } \\
\text { secondary prophylaxis } \\
\text { following two-stage } \\
\text { revision surgery for } \\
\text { prosthetic joint } \\
\text { infection }{ }^{20}\end{array}$ & $\begin{array}{l}\text { What is the effectiveness } \\
\text { and safety of oral antibiotic } \\
\text { prophylaxis following } \\
\text { completion of two-stage } \\
\text { revision surgery performed } \\
\text { following a first episode of } \\
\text { prosthetic joint infection? }\end{array}$ & $\begin{array}{l}\text { University of Pennsylvania } \\
\text { Health System executives } \\
\text { and clinicians }\end{array}$ & $\begin{array}{l}\text { Whether or not to recommend } \\
\text { antibiotic prophylaxis after } \\
\text { completion of two stage-revision } \\
\text { surgery, for those with a history of } \\
\text { prosthetic joint infection }\end{array}$ & $\begin{array}{l}\text { Strength of evidence base } \\
\text { limited by small size, } \\
\text { heterogeneity, and quality of } \\
\text { studies. Evidence does not } \\
\text { indicate an optimal treatment } \\
\text { regimen or duration of } \\
\text { therapy, or identify whether } \\
\text { the effectiveness of treatment } \\
\text { varies by patient } \\
\text { characteristics. Also low } \\
\text { strength evidence indicating } \\
\text { that oral antibiotic therapy } \\
\text { does not result in serious } \\
\text { AEs (not systematically } \\
\text { addressed across studies) }\end{array}$ \\
\hline $\begin{array}{l}\text { Effectiveness of Indoor } \\
\text { Allergen Reduction in } \\
\text { Management of Asthma }{ }^{21}\end{array}$ & $\begin{array}{l}\text { Among individuals with } \\
\text { asthma, what is the } \\
\text { effectiveness of } \\
\text { interventions to reduce or } \\
\text { remove exposures to } \\
\text { indoor inhalant allergens } \\
\text { on asthma control, } \\
\text { exacerbations, quality of } \\
\text { life, and other relevant } \\
\text { outcomes? }\end{array}$ & NHLBI guideline panel & $\begin{array}{l}\text { Whether to recommend air } \\
\text { purification for asthma patients }\end{array}$ & $\begin{array}{l}\text { Substantial inconsistency and } \\
\text { imprecision. } 1 \text { RCT (low risk } \\
\text { of bias) showed no } \\
\text { differences in asthma control } \\
\text { scores. } 1 \text { RCT (high risk of } \\
\text { bias) showed improvement in } \\
\text { combined asthma outcomes. } \\
1 \text { RCT (low risk of bias) did } \\
\text { not report differences in } \\
\text { asthma scores. }\end{array}$ \\
\hline $\begin{array}{l}\text { Effectiveness and Safety } \\
\text { of Bronchial } \\
\text { Thermoplasty in } \\
\text { Management of Asthma }{ }^{22}\end{array}$ & $\begin{array}{l}\text { What are the benefits and } \\
\text { harms of using BT in } \\
\text { addition to standard } \\
\text { treatment for the treatment } \\
\text { of adult ( } \geq 18 \text { years) } \\
\text { patients with asthma? }\end{array}$ & NHLBI guideline panel & $\begin{array}{l}\text { Whether to recommend bronchial } \\
\text { thermoplasty }\end{array}$ & $\begin{array}{l}\text { Study limitations; inability to } \\
\text { assess consistency given } \\
\text { only } 1 \text { study; unknown } \\
\text { imprecision given only } 1 \\
\text { study; no differences } \\
\text { observed between } \\
\text { intervention and control } \\
\text { groups, so unable to evaluate } \\
\text { magnitude of effect }\end{array}$ \\
\hline
\end{tabular}




\begin{tabular}{|c|c|c|c|c|}
\hline $\begin{array}{l}\text { Report Title } \\
\text { (43 articles) }\end{array}$ & Key Question & End-user & Decisional Dilemma & $\begin{array}{l}\text { Reason for Insufficient } \\
\text { Evidence Rating }\end{array}$ \\
\hline $\begin{array}{l}\text { Obesity Prevention } \\
\text { Interventions and } \\
\text { Implications for Energy } \\
\text { Balance in the United } \\
\text { States and Mexico: A } \\
\text { Systematic Review of the } \\
\text { Evidence and Meta- } \\
\text { Analysis }{ }^{23}\end{array}$ & $\begin{array}{l}\text { What are the effects of } \\
\text { obesity prevention policies } \\
\text { on energy consumed and } \\
\text { expended? }\end{array}$ & $\begin{array}{l}\text { Abstract public health policy } \\
\text { maker }\end{array}$ & $\begin{array}{l}\text { What policies can be implemented } \\
\text { to reduce obesity? }\end{array}$ & $\begin{array}{l}\text { Few studies reported } \\
\text { outcomes of interest (energy } \\
\text { consumption and } \\
\text { expenditure), and ever fewer } \\
\text { focused on children }\end{array}$ \\
\hline $\begin{array}{l}\text { A Systematic Review in } \\
\text { Support of the National } \\
\text { Consensus Project } \\
\text { Clinical Practice } \\
\text { Guidelines for Quality } \\
\text { Palliative Care, Fourth } \\
\text { Edition }^{24}\end{array}$ & $\begin{array}{l}\text { (KQ2) What is the impact } \\
\text { of palliative care } \\
\text { interventions on physical } \\
\text { symptom screening, } \\
\text { assessment, and } \\
\text { management of patients? } \\
\text { (KQ4) Does an } \\
\text { assessment of } \\
\text { environmental or social } \\
\text { needs as part of a } \\
\text { comprehensive palliative } \\
\text { assessment improve } \\
\text { needs identification and } \\
\text { access to relevant } \\
\text { services? } \\
\text { (KQ7a) What is the effect } \\
\text { of grief and bereavement } \\
\text { programs on } \\
\text { family/caregiver } \\
\text { outcomes? }\end{array}$ & NR & $\begin{array}{l}\text { "Inform National Consensus } \\
\text { Project (NCP) Clinical Practice } \\
\text { Guidelines for Quality } \\
\text { Palliative Care" }\end{array}$ & NR \\
\hline $\begin{array}{l}\text { Effects of medication } \\
\text { assisted treatment (MAT) } \\
\text { for opioid use disorder } \\
\text { on functional outcomes: } \\
\text { A systematic review }\end{array}$ & $\begin{array}{l}\text { What are the effects of } \\
\text { MAT (using } \\
\text { buprenorphine, } \\
\text { buprenorphine plus } \\
\text { naloxone, methadone, or } \\
\text { naltrexone) for OUD on } \\
\text { functional outcomes } \\
\text { compared to wait-list, } \\
\text { placebo, treatment without } \\
\text { medication, any other } \\
\text { comparator, or each other } \\
\text { (e.g., buprenorphine vs } \\
\text { naltrexone)? }\end{array}$ & Department of Defense & Palliative Care & Poor quality studies \\
\hline
\end{tabular}




\begin{tabular}{|c|c|c|c|c|}
\hline $\begin{array}{l}\text { Report Title } \\
\text { (43 articles) }\end{array}$ & Key Question & End-user & Decisional Dilemma & $\begin{array}{l}\text { Reason for Insufficient } \\
\text { Evidence Rating }\end{array}$ \\
\hline $\begin{array}{l}\text { Meditation for } \\
\text { Posttraumatic Stress } \\
\text { Disorder: A Systematic } \\
\text { Review }^{26}\end{array}$ & $\begin{array}{l}\text { What are the effects of } \\
\text { meditation interventions on } \\
\text { posttraumatic stress } \\
\text { disorder symptoms, } \\
\text { depression, anxiety, } \\
\text { health-related quality of } \\
\text { life, functional status, and } \\
\text { adverse events compared } \\
\text { with treatment as usual, } \\
\text { waitlists, no treatment, or } \\
\text { other active treatments, in } \\
\text { adults with posttraumatic } \\
\text { stress disorder? }\end{array}$ & $\begin{array}{l}\text { VA National Center for } \\
\text { Patient Safety }\end{array}$ & $\begin{array}{l}\text { Meditation approach, intervention } \\
\text { intensity, and study quality varied } \\
\text { considerably }\end{array}$ & $\begin{array}{l}\text { "meditation improved PTSD } \\
\text { symptoms and depression } \\
\text { symptoms. However, these } \\
\text { positive findings are based } \\
\text { on low to moderate ratings of } \\
\text { quality of evidence, and only } \\
\text { a small number of studies } \\
\text { were available in each } \\
\text { meditation category } \\
\text { Given the lack of } \\
\text { monotherapy studies, it was } \\
\text { not possible to determine } \\
\text { differential effects of } \\
\text { offering meditation as } \\
\text { adjunctive or monotherapy." }\end{array}$ \\
\hline $\begin{array}{l}\text { Wrong-site surgery, } \\
\text { retained surgical items, } \\
\text { and surgical fires: a } \\
\text { systematic review of } \\
\text { surgical never events }{ }^{27}\end{array}$ & $\begin{array}{l}\text { What is the effectiveness } \\
\text { of the individually identified } \\
\text { interventions for the } \\
\text { prevention of wrong site } \\
\text { surgery, retained surgical } \\
\text { items, and surgical fires? }\end{array}$ & $\begin{array}{l}\text { Veterans Affairs (VA) } \\
\text { managers and policymakers } \\
\text { VA National Center for } \\
\text { Patient Safety }\end{array}$ & $\begin{array}{l}\text { "improve the health and healthcare } \\
\text { of Veterans } \\
\text { Develop a standardized, single, } \\
\text { strong recommendation to VA } \\
\text { facilities in the effort to eliminate } \\
\text { wrong site surgery, retained } \\
\text { surgical items, and surgical fires." }\end{array}$ & $\begin{array}{l}\text { Despite promising } \\
\text { approaches and global } \\
\text { Universal Protocol } \\
\text { evaluations, empirical } \\
\text { evidence for interventions is } \\
\text { limited. }\end{array}$ \\
\hline $\begin{array}{l}\text { Adverse Effects of } \\
\text { Pharmacologic } \\
\text { Treatments of Major } \\
\text { Depression in Older } \\
\text { Adults }^{28}\end{array}$ & $\begin{array}{l}\text { To assess adverse effects } \\
\text { of pharmacologic } \\
\text { antidepressants for } \\
\text { treatment of major } \\
\text { depressive disorder (MDD) } \\
\text { in adults } 65 \text { years of age or } \\
\text { older. }\end{array}$ & $\begin{array}{l}\text { (?) Data used to create } \\
\text { report was all done by } \\
\text { investigators at EPC }\end{array}$ & $\begin{array}{l}\text { Are the adverse events severe } \\
\text { enough, persistent enough, or } \\
\text { consistent enough to warrant } \\
\text { reconsideration of use in patients } \\
65+.\end{array}$ & $\begin{array}{l}\text { risk of bias, imprecisions, } \\
\text { suspected selective reporting } \\
\text { bias, and withdrawal of } \\
\text { patients who had an adverse } \\
\text { event during the acute } \\
\text { period. }\end{array}$ \\
\hline
\end{tabular}




\begin{tabular}{|c|c|c|c|c|}
\hline $\begin{array}{l}\text { Report Title } \\
\text { (43 articles) }\end{array}$ & Key Question & End-user & Decisional Dilemma & $\begin{array}{l}\text { Reason for Insufficient } \\
\text { Evidence Rating }\end{array}$ \\
\hline $\begin{array}{l}\text { Association of Inhaled } \\
\text { Corticosteroids and } \\
\text { Long-Acting } \beta \text {-Agonists } \\
\text { as Controller and Quick } \\
\text { Relief Therapy with } \\
\text { Exacerbations and } \\
\text { Symptom Control in } \\
\text { Persistent Asthma }{ }^{29}\end{array}$ & $\begin{array}{l}\text { What is the efficacy } \\
\text { associated with using } \\
\text { inhaled corticosteroids and } \\
\text { long-acting } \beta \text {-agonists } \\
\text { (LABAs) together as both } \\
\text { the controller and the quick } \\
\text { relief therapy termed single } \\
\text { maintenance and reliever } \\
\text { therapy (SMART) in } \\
\text { patients with persistent } \\
\text { asthma? }\end{array}$ & $\begin{array}{l}\text { (?) Data used to create } \\
\text { report was all done by } \\
\text { investigators at EPC } \\
\text {. }\end{array}$ & $\begin{array}{l}\text { Whether the combination of LABAs } \\
+ \text { ICS should be used for both } \\
\text { quick relief and as a control }\end{array}$ & $\begin{array}{l}\text { risk of bias, inconsistency, } \\
\text { lack of directness, lack of } \\
\text { precision, and publication } \\
\text { bias }\end{array}$ \\
\hline $\begin{array}{l}\text { Comparative } \\
\text { Effectiveness of } \\
\text { Analgesics to Reduce } \\
\text { Acute Pain in the } \\
\text { Prehospital Setting }\end{array}$ & $\begin{array}{l}\text { What is the effectiveness } \\
\text { and harms of opioid and } \\
\text { nonopioid analgesics for } \\
\text { the treatment of moderate } \\
\text { to severe acute pain in the } \\
\text { prehospital setting? }\end{array}$ & $\begin{array}{l}\text { (?) Data used to create } \\
\text { report was all done by } \\
\text { investigators at EPC }\end{array}$ & $\begin{array}{l}\text { What agent is the best to use in } \\
\text { emergency settings to pain }\end{array}$ & $\begin{array}{l}\text { "Indirect evidence and not } \\
\text { many reports of adverse } \\
\text { events for treatments for } \\
\text { ketamine, NSAID, and } \\
\text { acetaminophen comparison. } \\
\text { in at } 15 \text { minutes. } \\
\text { Only one study for nitrous } \\
\text { oxide }\end{array}$ \\
\hline $\begin{array}{l}\text { Prolonged versus } \\
\text { standard-duration } \\
\text { venous } \\
\text { thromboprophylaxis in } \\
\text { major orthopedic } \\
\text { surgery: a systematic } \\
\text { review }^{31}\end{array}$ & $\begin{array}{l}\text { What are the benefits and } \\
\text { harms of prolonged versus } \\
\text { standard-duration } \\
\text { thromboprophylaxis after } \\
\text { major orthopedic surgery } \\
\text { in adults? }\end{array}$ & $\begin{array}{l}\text { (?) Data used to create } \\
\text { report was all done by } \\
\text { investigators at EPC }\end{array}$ & $\begin{array}{l}\text { Should standard or prolonged- } \\
\text { duration VTE prophylaxis be used } \\
\text { in knee replacement or hip fracture } \\
\text { surgery. }\end{array}$ & $\begin{array}{l}\text { Most trials had few events, } \\
\text { not much evidence for knee } \\
\text { replacement or hip fracture } \\
\text { surgery }\end{array}$ \\
\hline $\begin{array}{l}\text { Systematic review: } \\
\text { comparative } \\
\text { effectiveness of } \\
\text { adjunctive devices in } \\
\text { patients with ST- } \\
\text { segment elevation } \\
\text { myocardial infarction } \\
\text { undergoing } \\
\text { percutaneous coronary } \\
\text { intervention of native } \\
\text { vessels }^{32}\end{array}$ & $\begin{array}{l}\text { Compare effectiveness } \\
\text { and safety of adjunctive } \\
\text { devices to remove thrombi } \\
\text { or protect against STEMI } \\
\text { in patients undergoing PCl } \\
\text { of native vessels. }\end{array}$ & $\begin{array}{l}\text { (?) Data used to create } \\
\text { report was all done by } \\
\text { investigators at EPC }\end{array}$ & $\begin{array}{l}\text { Are medical devices safe and } \\
\text { effective long-term for patients with } \\
\text { STEMI }\end{array}$ & $\begin{array}{l}\text { Few trials followed patients } \\
\text { long-term and lack of data } \\
\text { regarding safety }\end{array}$ \\
\hline
\end{tabular}




\begin{tabular}{|c|c|c|c|c|}
\hline $\begin{array}{l}\text { Report Title } \\
\text { (43 articles) }\end{array}$ & Key Question & End-user & Decisional Dilemma & $\begin{array}{l}\text { Reason for Insufficient } \\
\text { Evidence Rating }\end{array}$ \\
\hline $\begin{array}{l}\text { Antipsychotics for the } \\
\text { Prevention and } \\
\text { Treatment of Delirium }\end{array}$ & Treatment of delirium & AGS & Updating BEERS criteria & $\begin{array}{l}\text { inconsistent; indirect; } \\
\text { imprecise; assessed delirium } \\
\text { severity using different } \\
\text { instruments in different } \\
\text { patient populations with } \\
\text { inconsistent results }\end{array}$ \\
\hline $\begin{array}{l}\text { Use of Cardiac } \\
\text { Resynchronization } \\
\text { Therapy }^{34}\end{array}$ & Use of specific CRT & CMS & Coverage decisions & $\begin{array}{l}\text { No direct comparison } \\
\text { reported (reported } \\
\text { comparison to optimal } \\
\text { medical therapy) }\end{array}$ \\
\hline $\begin{array}{l}\text { Renal Denervation in the } \\
\text { Medicare Population }^{35}\end{array}$ & $\begin{array}{l}\text { What is the evidence for } \\
\text { renal denervation } \\
\text { effectiveness in other } \\
\text { conditions such as heart } \\
\text { failure and arrhythmias? }\end{array}$ & CMS & Coverage decisions & $\begin{array}{l}\text { This was a technical brief, } \\
\text { and we did not perform the } \\
\text { usual grading of strength of } \\
\text { evidence. For this KQ, we } \\
\text { concluded that "data were } \\
\text { very limited on the efficacy } \\
\text { for conditions other than } \\
\text { resistant hypertension." } \\
\text { Under the usual grading } \\
\text { scheme, we would have } \\
\text { called this insufficient } \\
\text { evidence because there were } \\
\text { no large RCTs and the } \\
\text { available studies were very } \\
\text { small with a high risk of bias } \\
\text { and little consistency in how } \\
\text { outcomes were reported. }\end{array}$ \\
\hline $\begin{array}{l}\text { Management of Renal } \\
\text { Masses and Localized } \\
\text { Renal Cancer }\end{array}$ & $\begin{array}{l}\text { Efficacy and comparative } \\
\text { efficacy of different } \\
\text { interventions for the } \\
\text { management of a renal } \\
\text { mass suspicious for } \\
\text { localized renal cell } \\
\text { carcinoma }\end{array}$ & $\begin{array}{l}\text { American Urological } \\
\text { Association }\end{array}$ & $\begin{array}{l}\text { Used in updating their guidelines } \\
\text { on management options }\end{array}$ & $\begin{array}{l}\text { Evidence was insufficient on } \\
\text { a number of the comparisons } \\
\text { of interest. For some } \\
\text { comparisons and some } \\
\text { outcomes, there were no } \\
\text { studies. For other } \\
\text { comparisons and outcomes, } \\
\text { there were a few studies, but } \\
\text { the studies had high risk of } \\
\text { bias and important } \\
\text { differences between studies. }\end{array}$ \\
\hline
\end{tabular}




\begin{tabular}{|c|c|c|c|c|}
\hline $\begin{array}{l}\text { Interventions for } \\
\text { Substance Use } \\
\text { Disorders in } \\
\text { Adolescents: A } \\
\text { Systematic Review }{ }^{37}\end{array}$ & $\begin{array}{l}\text { What are the effects of } \\
\text { behavioral, pharmacologic, } \\
\text { and combined } \\
\text { interventions compared } \\
\text { with placebo or no active } \\
\text { treatment for substance } \\
\text { use disorders and } \\
\text { problematic substance use } \\
\text { in adolescents to achieve } \\
\text { abstinence, reduce } \\
\text { quantity and frequency of } \\
\text { use, improve functional } \\
\text { outcomes, and reduce } \\
\text { substance-related harms? }\end{array}$ & AACP & $\begin{array}{l}\text { Whether or not to recommend MI } \\
\text { with the goal of attaining } \\
\text { abstinence from alcohol, cannabis, } \\
\text { Whether or not to recommend } \\
\text { education with the goal of } \\
\text { decreasing substance related } \\
\text { problems. } \\
\text { Which nonbrief intervention or } \\
\text { combination of behavioral } \\
\text { interventions are superior among } \\
\text { active interventions. } \\
\text { Is buprenorphine more effective } \\
\text { than clonidine to reduce opioid use } \\
\text { or achieve abstinence. } \\
\text { Does memantadine in addition to } \\
\text { buprenorphine lead to higher rates } \\
\text { of abstinence and/or less use. } \\
\text { Does cyanamide compared to } \\
\text { placebo reduce alcohol use or } \\
\text { increase abstinence? } \\
\text { Should disulfiram or naltrexone be } \\
\text { recommended to reduce alcohol } \\
\text { use or increase abstinence in } \\
\text { adolescents with alcohol use } \\
\text { disorder? } \\
\text { Which treatment (combined with } \\
\text { Educ), Naltrexone or Disulfiram } \\
\text { should be recommended to reduce } \\
\text { alcohol use or increase } \\
\text { abstinence? } \\
\text { Should treatment with N- } \\
\text { acetylcysteine be recommended } \\
\text { for cannabis use disorder, in } \\
\text { addition to case management? } \\
\text { Should treatment with topiramate } \\
\text { be recommended for cannabis use }\end{array}$ & $\begin{array}{l}\text { Imprecise with moderate risk } \\
\text { of bias } \\
\text { Imprecise, unclear } \\
\text { consistency of sparse } \\
\text { evidence network } \\
\text { Single very small study } \\
\text { inconsistent effect }\end{array}$ \\
\hline
\end{tabular}




\begin{tabular}{|c|c|c|c|c|}
\hline $\begin{array}{l}\text { Report Title } \\
\text { (43 articles) }\end{array}$ & Key Question & End-user & Decisional Dilemma & $\begin{array}{l}\text { Reason for Insufficient } \\
\text { Evidence Rating }\end{array}$ \\
\hline & & & $\begin{array}{l}\text { disorder, in addition to motivational } \\
\text { interviewing? }\end{array}$ & \\
\hline $\begin{array}{l}\text { Nonsurgical Treatments } \\
\text { for Urinary Incontinence } \\
\text { in Women: A Systematic } \\
\text { Review Update }^{38}\end{array}$ & $\begin{array}{l}\text { Key Questions 1-4: What } \\
\text { are the benefits and harms } \\
\text { of nonpharmacological and } \\
\text { pharmacological (and } \\
\text { combination) treatments of } \\
\text { Ul in women, and how do } \\
\text { they compare with each } \\
\text { other? }\end{array}$ & \begin{tabular}{|l} 
PCORI, Public \\
\end{tabular} & $\begin{array}{l}\text { Effective and most effective } \\
\text { interventions for women to } \\
\text { manage stress and urge UI }\end{array}$ & $\begin{array}{l}\text { 1. Combination of indirect } \\
\text { evidence only (indirect } \\
\text { comparison in NMA) and } \\
\text { imprecise estimate. } \\
\text { 2. Lack of evidence (for } \\
\text { subgroup analyses of } \\
\text { interest) } \\
\text { 3. Combination of } \\
\text { inconsistent (discordant) and } \\
\text { imprecise ratings in EP. }\end{array}$ \\
\hline $\begin{array}{l}\text { Lower Limb Prostheses: } \\
\text { Measurement } \\
\text { Instruments, } \\
\text { Comparison of } \\
\text { Component Effects by } \\
\text { Subgroups, and Long- } \\
\text { Term Outcomes }{ }^{39}\end{array}$ & $\begin{array}{l}\text { KQ 4. In adults who use a } \\
\text { lower limb prosthesis, how } \\
\text { do ambulatory, functional, } \\
\text { and patient-centered } \\
\text { outcomes with different } \\
\text { prosthetic components } \\
\text { vary based on study } \\
\text { participant characteristics? } \\
\text { KQ 6. What is the level of } \\
\text { patient satisfaction with the } \\
\text { process of accessing an } \\
\text { LLP (including experiences } \\
\text { with both providers and } \\
\text { payers)? } \\
\text { KQ 7. At } 6 \text { months, } 1 \text { year, } \\
\text { and } 5 \text { years after receipt of } \\
\text { an LLP, (accounting for } \\
\text { intervening mortality, } \\
\text { subsequent surgeries, or } \\
\text { injuries) what percentage } \\
\text { of individuals... (various } \\
\text { outcomes)? }\end{array}$ & $\begin{array}{l}\text { CMS, prosthesis researchers } \\
\text { and clinicians }\end{array}$ & $\begin{array}{l}\text { Choice of the appropriate lower } \\
\text { limb prosthesis for individual } \\
\text { amputees }\end{array}$ & $\begin{array}{l}\text { KQ 4. Single study (also high } \\
\text { RoB, single study, indirect-- } \\
\text { highly limited applicability). } \\
\text { KQ 5. Lack of evidence/no } \\
\text { studies } \\
\text { KQ 7. Single study (also } \\
\text { indirect--limited applicability } \\
\text { to primary population of } \\
\text { interest [CMS]) } \\
\text { KQ 7. Inconsistent findings } \\
\text { across studies (differences in } \\
\text { directionality of findings); no } \\
\text { meta-analysis possible }\end{array}$ \\
\hline
\end{tabular}




\begin{tabular}{|c|c|c|c|c|}
\hline $\begin{array}{l}\text { Report Title } \\
\text { (43 articles) }\end{array}$ & Key Question & End-user & Decisional Dilemma & $\begin{array}{l}\text { Reason for Insufficient } \\
\text { Evidence Rating }\end{array}$ \\
\hline $\begin{array}{l}\text { WHO guidelines for the } \\
\text { pharmacological and } \\
\text { radiotherapeutic } \\
\text { management of cancer } \\
\text { pain in adults and } \\
\text { adolescents }^{40}\end{array}$ & $\begin{array}{l}\text { 1. Choice of } \\
\text { pharmacotherapy for } \\
\text { analgesia (for cancer pain) } \\
\text { 2. Effect and harms of } \\
\text { opioid switching/rotation } \\
\text { 3. Comparison of opioid } \\
\text { formulations } \\
\text { 4. Comparisons regimens } \\
\text { for ceasing opioids } \\
\text { 5. Comparative effects and } \\
\text { harms of adjuvant } \\
\text { therapies (steroids, } \\
\text { bisphosphonates, } \\
\text { antidepressants, } \\
\text { antiepileptics) } \\
\text { 6. Radiotherapy for } \\
\text { (painful) bone metastases }\end{array}$ & WHO for international CPG & $\begin{array}{l}\text { Safe and effective treatment of } \\
\text { cancer pain with minimization of } \\
\text { AEs }\end{array}$ & $\begin{array}{l}\text { Marching across GRADE } \\
\text { table to achieve Very Low }\end{array}$ \\
\hline $\begin{array}{l}\text { KDIGO Clinical Practice } \\
\text { Guidelines for the } \\
\text { Prevention, Diagnosis, } \\
\text { Evaluation, and } \\
\text { Treatment of Hepatitis C } \\
\text { in Chronic Kidney } \\
\text { Disease }^{41}\end{array}$ & $\begin{array}{l}\text { Multiple KQs to cover } 12 \\
\text { Guideline topics. Testing } \\
\text { for HCV, Determination of } \\
\text { whether to treat HCV, } \\
\text { Choice of HCV treatment, } \\
\text { Preventing HCV } \\
\text { transmission, Issues } \\
\text { pertaining to kidney } \\
\text { transplantation, Diagnosis } \\
\text { of HCV-related kidney } \\
\text { diseases, Treatment of } \\
\text { HCV-related kidney } \\
\text { diseases }\end{array}$ & $\begin{array}{l}\text { KDIGO CPG development } \\
\text { workgroup, patients, } \\
\text { clinicians }\end{array}$ & $\begin{array}{l}\text { Best and appropriate management } \\
\text { of patients with CKD and HCV } \\
\text { infection (or risk of exposure) }\end{array}$ & $\begin{array}{l}\text { Marching across GRADE } \\
\text { table to achieve Very Low }\end{array}$ \\
\hline
\end{tabular}




\begin{tabular}{|c|c|c|c|c|}
\hline $\begin{array}{l}\text { Report Title } \\
\text { (43 articles) }\end{array}$ & Key Question & End-user & Decisional Dilemma & $\begin{array}{l}\text { Reason for Insufficient } \\
\text { Evidence Rating }\end{array}$ \\
\hline $\begin{array}{l}\text { First- and Second- } \\
\text { Generation } \\
\text { Antipsychotics in } \\
\text { Children and Young } \\
\text { Adults: Systematic } \\
\text { Review Update }{ }^{42}\end{array}$ & $\begin{array}{l}\text { KQ 1: What are the } \\
\text { benefits, in terms of } \\
\text { intermediate and } \\
\text { effectiveness outcomes, of } \\
\text { first and second generation } \\
\text { antipsychotics-at the } \\
\text { level of individual } \\
\text { antipsychotics and across } \\
\text { each class-in } \\
\text { comparisons with placebo, } \\
\text { different doses of the same } \\
\text { antipsychotic, or different } \\
\text { antipsychotics in children } \\
\text { and young adults ( } \leq 24 \\
\text { years)? } \\
\text { KQ 2: Across all conditions } \\
\text { of interest, what are the } \\
\text { harms of first- and second- } \\
\text { generation } \\
\text { antipsychotics-at the } \\
\text { level of individual } \\
\text { antipsychotics and across } \\
\text { each class-in } \\
\text { comparisons with placebo, } \\
\text { different doses of the same } \\
\text { antipsychotic, or different } \\
\text { antipsychotics in children } \\
\text { and young adults ( } \leq 24 \\
\text { years)? }\end{array}$ & $\begin{array}{l}\text { American Academy of Child } \\
\text { and Adolescent Psychiatry }\end{array}$ & $\begin{array}{l}\text { Best and appropriate management } \\
\text { of patients with CKD and HCV } \\
\text { infection (or risk of exposure) } \\
\text { SGAs for treatment resistant } \\
\text { eating disorders } \\
\text { Effects with long-term treatment for } \\
\text { bipolar disorder } \\
\text { What SGA may have lower major } \\
\text { AEs over short- or long-term } \\
\text { treatment }\end{array}$ & $\begin{array}{l}\text { Marching across GRADE } \\
\text { table to achieve Very Low } \\
\text { Failure to provide data by } \\
\text { group (for determining } \\
\text { consistency and precision) } \\
\text { and the small sample sizes } \\
\text { (imprecision) were the main } \\
\text { reasons } \\
\text { ROB, inconsistency and } \\
\text { imprecision } \\
\text { Data for rare AEs was mostly } \\
\text { from single studies having } \\
\text { small sample sizes and } \\
\text { moderate or higher ROB, } \\
\text { therefore SOE was deemed } \\
\text { insufficient. }\end{array}$ \\
\hline
\end{tabular}




\begin{tabular}{|c|c|c|c|c|}
\hline $\begin{array}{l}\text { Report Title } \\
\text { (43 articles) }\end{array}$ & Key Question & End-user & Decisional Dilemma & $\begin{array}{l}\text { Reason for Insufficient } \\
\text { Evidence Rating }\end{array}$ \\
\hline $\begin{array}{l}\text { Behavioral Programs for } \\
\text { Type } 1 \text { Diabetes Mellitus: } \\
\text { A Systematic Review } \\
\text { and Meta-analysis }^{43}\end{array}$ & $\begin{array}{l}\text { KQ 1: For patients with } \\
\text { T1DM, are behavioral } \\
\text { programs } \\
\text { implemented in a } \\
\text { community health setting } \\
\text { effective compared with } \\
\text { usual } \\
\text { or standard care, or active } \\
\text { comparators in- } \\
\text { a. Improving behavioral, } \\
\text { clinical, and health } \\
\text { outcomes? } \\
\text { b. Improving diabetes- } \\
\text { related health care } \\
\text { utilization? } \\
\text { c. Achieving program } \\
\text { acceptability as measured } \\
\text { by participant attrition } \\
\text { rates? }\end{array}$ & $\begin{array}{l}\text { No identified end user for } \\
\text { this one; public nomination }\end{array}$ & $\begin{array}{l}\text { Whether and what type of program } \\
\text { to implement }\end{array}$ & $\begin{array}{l}\text { QoL: ROB, inconsistency (or } \\
\text { lack of consistency due to } \\
\text { one study), and imprecision. } \\
\text { No trials reported on micro- } \\
\text { and macrovascular } \\
\text { complications or on all-cause } \\
\text { mortality }\end{array}$ \\
\hline
\end{tabular}




\section{References}

1. Viswanathan M, Reddy S, Berkman N, et al. Screening to Prevent Osteoporotic Fractures: Updated Evidence Report and Systematic Review for the US Preventive Services Task Force. JAMA. 2018;319(24):2532-51. doi: 10.1001/jama.2018.6537. PMID: 29946734.

2. Berkman N, Wallace I, L W, et al. Speech and language delay and disorders in children age 5 and younger: screening. July 2015. Agency for Healthcare Research and Quality (US). 2015;Report No.: 13-05197-EF-1. PMID: 26225412.

3. Jonas DE, Reddy S, Middleton JC, et al. Screening for cardiovascular disease risk with resting or exercise electrocardiography: evidence report and systematic review for the US Preventive Services Task Force. JAMA. 2018;319(22):2315-28. doi: 10.1001/jama.2018.6897. PMID: 29896633.

4. Jonas DE, Kahwati LC, Yun JD, et al. Screening for atrial fibrillation with electrocardiography: evidence report and systematic review for the US Preventive Services Task Force. JAMA. 2018;320(5):485-98. doi: 10.1001/jama.2018.4190. PMID: 30088015.

5. RTI International-University of North Carolina Evidence-based Practice Center. Whole Exome Sequencing. Washington State Health Care Authority. 2019. doi: https:/www.hca.wa.gov/assets/program/wh ole-exome-sequencing-final-rpt20191022.pdf.

6. Patnode CD, Perdue LA, Rushkin M, et al. Screening for Unhealthy Drug Use in Primary Care in Adolescents and Adults, Including Pregnant Persons: Updated Systematic Review for the US Preventive Services Task Force. Agency for Healthcare Research and Quality. 2020;Report No.: 1905255-EF-1 doi:

https://www.uspreventiveservicestaskforce.o $\mathrm{rg} / \mathrm{uspstf} /$ document/final-evidence-reviewscreening/drug-use-illicit-screening.

7. Webber E, Thomas R, Lin JS. Implications of Multigene Panels for Hereditary Breast Cancer Risk Assessment. Not yet published.
8. Guirguis-Blake JM, Evans CV, Redmond N, et al. Screening for peripheral artery disease using the Ankle-Brachial Index: updated evidence report and systematic review for the US preventive services task force. JAMA. 2018;320(2):184-96. doi: 10.1001/jama.2018.4250. PMID: 29998343.

9. Guirguis-Blake JM, Henderson JT, Perdue LA. Periodic screening pelvic examination: evidence report and systematic review for the US Preventive Services Task Force. JAMA. 2017;317(9):954-66. doi: 10.1001/jama.2016.12819. PMID: 28267861.

10. Henrikson N, EJ AB, Blasi P, et al. Screening for Pancreatic Cancer: Updated Evidence Report and Systematic Review for the US Preventive Services Task Force. JAMA. 2019;322(5):445-54. doi: doi:10.1001/jama.2019.6190. PMID: 31386140 .

11. Henrikson NB, Morrison C, Blasi P, et al. Behavioral counseling for skin cancer prevention: A systematic evidence review for the US preventive services task force. JAMA. 2018. doi: 10.1001/jama.2017.21630. PMID: $29558557 \mathrm{~S}$.

12. Dunn J, Henrikson NB, Morrison CC, et al. Screening for Adolescent Idiopathic Scoliosis: Evidence Report and Systematic Review for the US Preventive Services Task Force. JAMA. 2018;319(2):173-87. doi: 10.1001/jama.2017.11669. PMID: 29318283.

13. Wang Z, Whiteside SP, Sim L, et al. Comparative effectiveness and safety of cognitive behavioral therapy and pharmacotherapy for childhood anxiety disorders: a systematic review and meta-analysis. JAMA Pediatr. 2017;171(11):1049-56. doi: 10.1001/jamapediatrics.2017.3036. PMID: 28859190. 
14. Wang Z, Pianosi P, Keogh K, et al. The clinical utility of fractional exhaled nitric oxide (FeNO) in asthma management. Agency for Healthcare Research and Quality (US). 2017;Report No.: 17(18)-EHC030-EF. PMID: 29533572.

15. Dobler CC, Morrow AS, Farah MH, et al. Pharmacologic and Nonpharmacologic Therapies in Adult Patients With Exacerbation of COPD: A Systematic Review. Agency for Healthcare Research and Quality (US). 2019; Report No.: 19(20)EHC024-EF. PMID: 31657888.

16. Liem RI, Lanzkron S, D. Coates T, et al. American Society of Hematology 2019 guidelines for sickle cell disease: cardiopulmonary and kidney disease. Blood Adv. 2019;3(23):3867-97. doi: 10.1182/bloodadvances.2019000916. PMID: 31794601 .

17. Eastell R, Rosen CJ, Black DM, et al. Pharmacological management of osteoporosis in postmenopausal women: an Endocrine Society clinical practice guideline. J Clin Endocrinol Metab. 2019;104(5):1595-622. doi: 10.1210/jc.2019-00221. PMID: 30907953.

18. Singh J, Guyatt G, Ogdie A, et al. 2018 American College of Rheumatology/National Psoriasis Foundation Guideline for the Treatment of Psoriatic Arthritis. Arthritis Care Res (Hoboken). 2018;71(1):2-29. doi: 10.1002/acr.23789. PMID: 30499259.

19. Leas B, Han J, Ziegler M, et al. Testing for clostridium difficile in oncology patients. University of Pennsylvania Center for Evidence-based Practice 2018.

20. Leas B, C U. Oral antibiotics for secondary prophylaxis following two-stage revision surgery for prosthetic joint infection. University of Pennsylvania Center for Evidence-based Practice. 2017.

21. Leas BF, D'Anci KE, Apter AJ, et al. Effectiveness of Indoor Allergen Reduction in Asthma Management: A Systematic Review. J Allergy Clin Immunol. 2018;141(5):1854-69. doi: 10.1016/j.jaci.2018.02.001. PMID: 29452202 .
22. D’Anci KE, Lynch MP, Leas BF, et al. Effectiveness and safety of bronchial thermoplasty in management of asthma. Agency for Healthcare Research and Quality (US). 2017;Report No.: 18-EHC003-EF. PMID: 29659226.

23. Richardson AS, Chen C, Sturm R, et al. Obesity Prevention Interventions and Implications for Energy Balance in the United States and Mexico: A Systematic Review of the Evidence and Meta-Analysis. Obesity (Silver Spring). 2019;27(9):1390-403. doi: 10.1002/oby.22540. PMID: 31325241.

24. Ahluwalia S, Chen C, Raaen L, et al. A Systematic Review in Support of the National Consensus Project Clinical Practice Guidelines for Quality Palliative Care, Fourth Edition. J Pain Symptom Manage. 2018;56(6). doi: 10.1016/j.jpainsymman.2018.09.008. PMID: 30391049.

25. Maglione MA, Raaen L, Chen C, et al. Effects of medication assisted treatment (MAT) for opioid use disorder on functional outcomes: a systematic review. J Subst Abuse Treat. 2018;89:28-51. doi: 10.1016/j.jsat.2018.03.001. PMID: 29706172.

26. Hilton L, Maher AR, Colaiaco B, et al. Meditation for Posttraumatic Stress Disorder: A Systematic Review. Psychol Trauma. 2017;9(4). doi: 10.1037/tra0000180. PMID: 27537781.

27. Hempel S, Maggard-Gibbons M, Nguyen DK, et al. Wrong-site surgery, retained surgical items, and surgical fires: a systematic review of surgical never events. JAMA Surg. 2015;150(8):796-805. doi: 10.1001/jamasurg.2015.0301. PMID: 26061125.

28. Sobieraj DM, Martinez BK, Hernandez AV, et al. Adverse effects of pharmacologic treatments of major depression in older adults. J Am Geriatr Soc. 2019;67(8):1571-81. doi: 10.1111/jgs.15966. PMID: 31140587. 
29. Sobieraj DM, Weeda ER, Nguyen E, et al. Association of inhaled corticosteroids and long-acting $\beta$-agonists as controller and quick relief therapy with exacerbations and symptom control in persistent asthma: a systematic review and meta-analysis. JAMA. 2018;319(14):1485-96. doi: 10.1001/jama.2018.2769. PMID: 29554195.

30. Sobieraj DM, Martinez BK, Miao B, et al. Comparative effectiveness of analgesics to reduce acute pain in the prehospital setting. Prehosp Emerg Care. 2020;24(2):163-74. doi: 10.1080/10903127.2019.1657213. PMID: 31476930.

31. Sobieraj DM, Lee S, Coleman CI, et al. Prolonged versus standard-duration venous thromboprophylaxis in major orthopedic surgery: a systematic review. Ann Intern Med. 2012;156(10):720-7. doi: 10.7326/0003-4819-156-10-20120515000423. PMID: 22412039.

32. Sobieraj DM, White CM, Kluger J, et al. Systematic review: comparative effectiveness of adjunctive devices in patients with ST-segment elevation myocardial infarction undergoing percutaneous coronary intervention of native vessels. BMC Cardiovasc Disord. 2011;11:74. doi: 10.1186/1471-2261-11-74. PMID: 22185559.

33. Neufeld KJ, Needham DM, Oh ES, et al. Antipsychotics for the prevention and treatment of delirium. Agency for Healthcare Research and Quality (US). 2019;Report No.: 19-EHC019-EF. PMID: 31509366.

34. Michtalik H, Sinha S, Sharma R, et al. Use of Cardiac Resynchronization Therapy. Agency for Healthcare Research and Quality (US). 2019.

35. Shafi T, Chacko M, Berger Z, et al. Renal denervation in the medicare population. Agency for Healthcare Research and Quality (US). 2016. PMID: 27748085.

36. Pierorazio PM, Johnson MH, Patel HD, et al. Management of renal masses and localized renal cancer: systematic review and metaanalysis. J Urol. 2016;196(4):989-99.

PMID: 27157369.
37. Steele DW, Becker SJ, Danko KJ, et al. Interventions for Substance Use Disorders in Adolescents: A Systematic Review. Agency for Healthcare Research and Quality (US). 2020;Report No.: 20-EHC014. PMID: 32479039.

38. Balk E, Adam GP, Kimmel H, et al. Nonsurgical treatments for urinary incontinence in women: a systematic review update. Agency for Healthcare Research and Quality (US). 2018;Report No.: 18-EHC016-EF. PMID: 30516945.

39. Balk EM, Gazula A, Markozannes G, et al. Lower limb prostheses: measurement instruments, comparison of component effects by subgroups, and long-term outcomes. Agency for Healthcare Research and Quality (US). 2018;Report No.: 18EHC017-EF. PMID: 30285344.

40. World Health Organization. WHO guidelines for the pharmacological and radiotherapeutic management of cancer pain in adults and adolescents. Licence: CC BY-NC-SA 30 IGO. Geneva; 2018.

41. Kidney Disease: Improving Global Outcomes (KDIGO) Hepatitis C Work Group. KDIGO 2018 Clinical Practice Guideline for the Prevention, Diagnosis, Evaluation, and Treatment of Hepatitis C in Chronic Kidney Disease. Kidney Int Suppl. 2018;8(3):91165. doi: 10.1016/j.kisu.2018.06.001. PMID: 30675443.

42. Pillay J, Boylan K, Carrey N, et al. First-and second-generation antipsychotics in children and young adults: systematic review update. Agency for Healthcare Research and Quality (US). 2017; Report No.: 17-EHC001-EF. PMID: 28749632.

43. Pillay J, Armstrong M, Butalia S, et al. Behavioral Programs for Type 1 Diabetes Mellitus: A Systematic Review and Metaanalysis. Ann Intern Med. 2015;163:836-47. doi: 10.7326/M15-1399. PMID: 26414020. 


\section{Appendix D. Review of Technical Briefs}

Table D-1. List of technical briefs

\begin{tabular}{|c|c|c|c|c|c|c|c|c|c|c|c|c|}
\hline $\begin{array}{l}\text { Technical } \\
\text { Brief Title } \\
\text { and Year } \\
\text { Accepted }\end{array}$ & Nominator & $\begin{array}{l}\text { Interventi } \\
\text { on study? }\end{array}$ & $\begin{array}{l}\text { Reported } \\
\text { on } \\
\text { outcomes } \\
?\end{array}$ & $\begin{array}{l}\text { Does it } \\
\text { make } \\
\text { recom } \\
\text { mendat } \\
\text { ions? }\end{array}$ & $\begin{array}{l}\text { Graded } \\
\text { SOE }\end{array}$ & $\begin{array}{l}\text { Risk } \\
\text { of } \\
\text { Bias } \\
\text { Asse } \\
\text { ssme } \\
\text { nt }\end{array}$ & $\begin{array}{l}\text { Meta- } \\
\text { analys } \\
\text { is }\end{array}$ & $\begin{array}{l}\text { Formal } \\
\text { Qualitat } \\
\text { ive } \\
\text { Method } \\
\text { s }\end{array}$ & $\begin{array}{l}\text { KI } \\
\text { contribut } \\
\text { ed to } \\
\text { findings }\end{array}$ & $\begin{array}{l}\text { Performed } \\
\text { grey } \\
\text { literature } \\
\text { searches }\end{array}$ & $\begin{array}{l}\text { Major issues } \\
\text { with KI } \\
\text { interviews } \\
\text { discussed in } \\
\text { peer review } \\
\text { feedback }\end{array}$ & $\begin{array}{l}\text { Major issues } \\
\text { with scoping } \\
\text { of review } \\
\text { discussed in } \\
\text { peer review } \\
\text { feedback }\end{array}$ \\
\hline $\begin{array}{l}\text { Transition } \\
\text { Care for } \\
\text { Children } \\
\text { with } \\
\text { Special } \\
\text { Health } \\
\text { Needs }^{1} \\
2014\end{array}$ & Researcher & Yes & Yes & No & No & No & No & No & Yes & Yes & No & Yes (setting) \\
\hline $\begin{array}{l}\text { Decision } \\
\text { Aids for } \\
\text { Advance } \\
\text { Care } \\
\text { Planning } \\
\\
2014\end{array}$ & Physician & Yes & Yes & Yes & No & No & No & No & Yes & Yes & No & No \\
\hline $\begin{array}{l}\text { Imaging } \\
\text { Technique } \\
\text { s for } \\
\text { Treatment } \\
\text { Evaluation } \\
\text { for } \\
\text { Metastatic } \\
\text { Breast } \\
\text { Cancer } \\
\\
2014\end{array}$ & $\begin{array}{l}\text { Tufts } \\
\text { Medical } \\
\text { Center } \\
\text { Evidence- } \\
\text { based } \\
\text { Practice } \\
\text { Center }\end{array}$ & Yes & Yes & Yes & No & No & No & No & Yes & Yes & $\begin{array}{l}\text { Yes (not enough } \\
\text { info) }\end{array}$ & Yes (cost) \\
\hline
\end{tabular}




\begin{tabular}{|c|c|c|c|c|c|c|c|c|c|c|c|c|}
\hline $\begin{array}{l}\text { Technical } \\
\text { Brief Title } \\
\text { and Year } \\
\text { Accepted }\end{array}$ & Nominator & $\begin{array}{l}\text { Interventi } \\
\text { on study? }\end{array}$ & $\begin{array}{l}\text { Reported } \\
\text { on } \\
\text { outcomes } \\
?\end{array}$ & $\begin{array}{l}\text { Does it } \\
\text { make } \\
\text { recom } \\
\text { mendat } \\
\text { ions? }\end{array}$ & $\begin{array}{l}\text { Graded } \\
\text { SOE }\end{array}$ & $\begin{array}{l}\text { Risk } \\
\text { of } \\
\text { Bias } \\
\text { Asse } \\
\text { ssme } \\
\text { nt }\end{array}$ & $\begin{array}{l}\text { Meta- } \\
\text { analys } \\
\text { is }\end{array}$ & $\begin{array}{l}\text { Formal } \\
\text { Qualitat } \\
\text { ive } \\
\text { Method } \\
\text { s }\end{array}$ & $\begin{array}{l}\text { KI } \\
\text { contribut } \\
\text { ed to } \\
\text { findings }\end{array}$ & $\begin{array}{l}\text { Performed } \\
\text { grey } \\
\text { literature } \\
\text { searches }\end{array}$ & $\begin{array}{l}\text { Major issues } \\
\text { with KI } \\
\text { interviews } \\
\text { discussed in } \\
\text { peer review } \\
\text { feedback }\end{array}$ & $\begin{array}{l}\text { Major issues } \\
\text { with scoping } \\
\text { of review } \\
\text { discussed in } \\
\text { peer review } \\
\text { feedback }\end{array}$ \\
\hline $\begin{array}{l}\text { Relationsh } \\
\text { ip } \\
\text { Between } \\
\text { Use of } \\
\text { Quality } \\
\text { Measures } \\
\text { and } \\
\text { Improved } \\
\text { Outcomes } \\
\text { in Serious } \\
\text { Mental } \\
\text { Illness } \\
\\
2014\end{array}$ & $\begin{array}{l}\text { National } \\
\text { Alliance on } \\
\text { Mental } \\
\text { Illness }\end{array}$ & No & No & No & No & No & No & Yes & Yes & Yes & No & Yes (cost) \\
\hline $\begin{array}{l}\text { Public } \\
\text { Reporting } \\
\text { of Cost } \\
\text { Measures } \\
\text { in Health: } \\
\text { An } \\
\text { Environme } \\
\text { ntal Scan } \\
\text { of Current } \\
\text { Practices } \\
\text { and } \\
\text { Assessme } \\
\text { nt of } \\
\text { Consumer } \\
\text { Centeredn } \\
\text { ess }{ }^{5} \\
2015\end{array}$ & Unsure & No & No & No & No & No & No & No & No & No & No & $\begin{array}{l}\text { Yes } \\
\text { (interventions, } \\
\text { population) }\end{array}$ \\
\hline
\end{tabular}




\begin{tabular}{|c|c|c|c|c|c|c|c|c|c|c|c|c|}
\hline $\begin{array}{l}\text { Technical } \\
\text { Brief Title } \\
\text { and Year } \\
\text { Accepted }\end{array}$ & Nominator & $\begin{array}{l}\text { Interventi } \\
\text { on study? }\end{array}$ & $\begin{array}{l}\text { Reported } \\
\text { on } \\
\text { outcomes } \\
?\end{array}$ & $\begin{array}{l}\text { Does it } \\
\text { make } \\
\text { recom } \\
\text { mendat } \\
\text { ions? }\end{array}$ & $\begin{array}{l}\text { Graded } \\
\text { SOE }\end{array}$ & $\begin{array}{l}\text { Risk } \\
\text { of } \\
\text { Bias } \\
\text { Asse } \\
\text { ssme } \\
\text { nt }\end{array}$ & $\begin{array}{l}\text { Meta- } \\
\text { analys } \\
\text { is }\end{array}$ & $\begin{array}{l}\text { Formal } \\
\text { Qualitat } \\
\text { ive } \\
\text { Method } \\
\text { s }\end{array}$ & $\begin{array}{l}\text { KI } \\
\text { contribut } \\
\text { ed to } \\
\text { findings }\end{array}$ & $\begin{array}{l}\text { Performed } \\
\text { grey } \\
\text { literature } \\
\text { searches }\end{array}$ & $\begin{array}{l}\text { Major issues } \\
\text { with KI } \\
\text { interviews } \\
\text { discussed in } \\
\text { peer review } \\
\text { feedback }\end{array}$ & $\begin{array}{l}\text { Major issues } \\
\text { with scoping } \\
\text { of review } \\
\text { discussed in } \\
\text { peer review } \\
\text { feedback }\end{array}$ \\
\hline $\begin{array}{l}\text { Manageme } \\
\text { nt } \\
\text { Strategies } \\
\text { to Reduce } \\
\text { Psychiatri } \\
\text { C } \\
\text { Readmissi } \\
\text { ons }^{6} \\
2015\end{array}$ & $\begin{array}{l}\text { RTI-UNC } \\
\text { Evidence- } \\
\text { based } \\
\text { Practice } \\
\text { Center }\end{array}$ & Yes & Yes & No & No & No & No & No & Yes & Yes & No & $\begin{array}{l}\text { Yes } \\
\text { (population) }\end{array}$ \\
\hline $\begin{array}{l}\text { Core } \\
\text { Functional } \\
\text { ity for } \\
\text { Pediatric- } \\
\text { specific } \\
\text { Electronic } \\
\text { Health } \\
\text { Records }^{7} \\
2015\end{array}$ & $\begin{array}{l}\text { American } \\
\text { Academy of } \\
\text { Pediatrics } \\
(\text { AAP) }\end{array}$ & Yes & Yes & Yes & No & No & No & No & Yes & Yes & $\begin{array}{l}\text { Yes (not } \\
\text { representative) }\end{array}$ & No \\
\hline $\begin{array}{l}\text { Genetic } \\
\text { Testing for } \\
\text { Developm } \\
\text { ental } \\
\text { Disabilitie } \\
\text { s, } \\
\text { Intellectual } \\
\text { Disability } \\
\text { and } \\
\text { Autism } \\
\text { Spectrum } \\
\text { Disorders } \\
\\
\\
2015\end{array}$ & Physician & Yes & No & No & No & No & No & No & Yes & Yes & $\begin{array}{l}\text { Yes (not } \\
\text { representative) }\end{array}$ & $\begin{array}{l}\text { Yes } \\
\text { (population) }\end{array}$ \\
\hline
\end{tabular}




\begin{tabular}{|c|c|c|c|c|c|c|c|c|c|c|c|c|}
\hline $\begin{array}{l}\text { Technical } \\
\text { Brief Title } \\
\text { and Year } \\
\text { Accepted }\end{array}$ & Nominator & $\begin{array}{l}\text { Interventi } \\
\text { on study? }\end{array}$ & $\begin{array}{l}\text { Reported } \\
\text { on } \\
\text { outcomes } \\
?\end{array}$ & $\begin{array}{l}\text { Does it } \\
\text { make } \\
\text { recom } \\
\text { mendat } \\
\text { ions? }\end{array}$ & $\begin{array}{l}\text { Graded } \\
\text { SOE }\end{array}$ & $\begin{array}{l}\text { Risk } \\
\text { of } \\
\text { Bias } \\
\text { Asse } \\
\text { ssme } \\
\text { nt }\end{array}$ & $\begin{array}{l}\text { Meta- } \\
\text { analys } \\
\text { is }\end{array}$ & $\begin{array}{l}\text { Formal } \\
\text { Qualitat } \\
\text { ive } \\
\text { Method } \\
\text { s }\end{array}$ & $\begin{array}{l}\text { KI } \\
\text { contribut } \\
\text { ed to } \\
\text { findings }\end{array}$ & $\begin{array}{l}\text { Performed } \\
\text { grey } \\
\text { literature } \\
\text { searches }\end{array}$ & $\begin{array}{l}\text { Major issues } \\
\text { with KI } \\
\text { interviews } \\
\text { discussed in } \\
\text { peer review } \\
\text { feedback }\end{array}$ & $\begin{array}{l}\text { Major issues } \\
\text { with scoping } \\
\text { of review } \\
\text { discussed in } \\
\text { peer review } \\
\text { feedback }\end{array}$ \\
\hline $\begin{array}{l}\text { Environme } \\
\text { ntal } \\
\text { Cleaning } \\
\text { for the } \\
\text { Prevention } \\
\text { of } \\
\text { Healthcare } \\
\text { - } \\
\text { Associate } \\
\text { d } \\
\text { Infections } \\
\\
2015\end{array}$ & $\begin{array}{l}\text { 3M Hospital } \\
\text { Hygiene } \\
\text { Global } \\
\text { Advisory } \\
\text { Board }\end{array}$ & Yes & Yes & No & No & No & No & No & Yes & Yes & No & No \\
\hline $\begin{array}{l}\text { Disparities } \\
\text { Within } \\
\text { Serious } \\
\text { Mental } \\
\text { Illness }^{10} \\
\\
2016\end{array}$ & $\begin{array}{l}\text { National } \\
\text { Alliance for } \\
\text { Mental } \\
\text { Illness, } \\
\text { Urban Los } \\
\text { Angeles } \\
\text { Affiliate }\end{array}$ & Yes & Yes & No & No & No & No & No & Yes & Yes & No & No \\
\hline $\begin{array}{l}\text { Patient } \\
\text { Safety in } \\
\text { Ambulator } \\
\text { y } \\
\text { Settings }{ }^{11} \\
2016\end{array}$ & Unsure & Yes & No & No & No & No & No & Yes & Yes & Yes & $\begin{array}{l}\text { Yes (not enough } \\
\text { info) }\end{array}$ & No \\
\hline
\end{tabular}




\begin{tabular}{|c|c|c|c|c|c|c|c|c|c|c|c|c|}
\hline $\begin{array}{l}\text { Technical } \\
\text { Brief Title } \\
\text { and Year } \\
\text { Accepted }\end{array}$ & Nominator & $\begin{array}{l}\text { Interventi } \\
\text { on study? }\end{array}$ & $\begin{array}{l}\text { Reported } \\
\text { on } \\
\text { outcomes } \\
?\end{array}$ & $\begin{array}{l}\text { Does it } \\
\text { make } \\
\text { recom } \\
\text { mendat } \\
\text { ions? }\end{array}$ & $\begin{array}{l}\text { Graded } \\
\text { SOE }\end{array}$ & $\begin{array}{l}\text { Risk } \\
\text { of } \\
\text { Bias } \\
\text { Asse } \\
\text { ssme } \\
\text { nt } \\
\end{array}$ & $\begin{array}{l}\text { Meta- } \\
\text { analys } \\
\text { is }\end{array}$ & $\begin{array}{l}\text { Formal } \\
\text { Qualitat } \\
\text { ive } \\
\text { Method } \\
\text { s }\end{array}$ & $\begin{array}{l}\text { KI } \\
\text { contribut } \\
\text { ed to } \\
\text { findings }\end{array}$ & $\begin{array}{l}\text { Performed } \\
\text { grey } \\
\text { literature } \\
\text { searches }\end{array}$ & $\begin{array}{l}\text { Major issues } \\
\text { with KI } \\
\text { interviews } \\
\text { discussed in } \\
\text { peer review } \\
\text { feedback }\end{array}$ & $\begin{array}{l}\text { Major issues } \\
\text { with scoping } \\
\text { of review } \\
\text { discussed in } \\
\text { peer review } \\
\text { feedback }\end{array}$ \\
\hline $\begin{array}{l}\text { Telehealth } \\
\text { : Mapping } \\
\text { the } \\
\text { Evidence } \\
\text { for Patient } \\
\text { Outcomes } \\
\text { from } \\
\text { Systemati } \\
\text { c } \\
\text { Reviews }{ }^{12} \\
2016\end{array}$ & Unsure & Yes & Yes & No & No & No & $\begin{array}{l}\text { No (but } \\
\text { pooled } \\
\text { SOEs } \\
\text { for } \\
\text { bubble } \\
\text { plot) }\end{array}$ & No & No & Yes & No & No \\
\hline $\begin{array}{l}\text { Resident } \\
\text { Safety } \\
\text { Practices } \\
\text { in Nursing } \\
\text { Home } \\
\text { Settings }^{13} \\
2016\end{array}$ & Unsure & Yes & Yes & No & No & Yes & No & No & No & No & No & Yes \\
\hline $\begin{array}{l}\text { Strategies } \\
\text { for } \\
\text { Improving } \\
\text { the Lives } \\
\text { of Women } \\
\text { Aged } 40 \\
\text { and Above } \\
\text { Living with } \\
\text { HIVIAIDS }{ }^{14} \\
2016\end{array}$ & $\begin{array}{l}\text { Office for } \\
\text { Women's } \\
\text { Health }\end{array}$ & Yes & No & No & No & No & No & No & No & No & No & Yes \\
\hline
\end{tabular}




\begin{tabular}{|c|c|c|c|c|c|c|c|c|c|c|c|c|}
\hline $\begin{array}{l}\text { Technical } \\
\text { Brief Title } \\
\text { and Year } \\
\text { Accepted }\end{array}$ & Nominator & $\begin{array}{l}\text { Interventi } \\
\text { on study? }\end{array}$ & $\begin{array}{l}\text { Reported } \\
\text { on } \\
\text { outcomes } \\
?\end{array}$ & $\begin{array}{l}\text { Does it } \\
\text { make } \\
\text { recom } \\
\text { mendat } \\
\text { ions? }\end{array}$ & $\begin{array}{l}\text { Graded } \\
\text { SOE }\end{array}$ & $\begin{array}{l}\text { Risk } \\
\text { of } \\
\text { Bias } \\
\text { Asse } \\
\text { ssme } \\
\text { nt }\end{array}$ & $\begin{array}{l}\text { Meta- } \\
\text { analys } \\
\text { is }\end{array}$ & $\begin{array}{l}\text { Formal } \\
\text { Qualitat } \\
\text { ive } \\
\text { Method } \\
\text { s }\end{array}$ & $\begin{array}{l}\text { KI } \\
\text { contribut } \\
\text { ed to } \\
\text { findings }\end{array}$ & $\begin{array}{l}\text { Performed } \\
\text { grey } \\
\text { literature } \\
\text { searches }\end{array}$ & $\begin{array}{l}\text { Major issues } \\
\text { with KI } \\
\text { interviews } \\
\text { discussed in } \\
\text { peer review } \\
\text { feedback }\end{array}$ & $\begin{array}{l}\text { Major issues } \\
\text { with scoping } \\
\text { of review } \\
\text { discussed in } \\
\text { peer review } \\
\text { feedback }\end{array}$ \\
\hline $\begin{array}{l}\text { Medication } \\
\text {-Assisted } \\
\text { Treatment } \\
\text { Models of } \\
\text { Care for } \\
\text { Opioid } \\
\text { Use } \\
\text { Disorder } \\
\text { in Primary } \\
\text { Care } \\
\text { Settings }{ }^{15} \\
2016\end{array}$ & Unsure & Yes & Yes & No & No & No & No & No & Yes & Yes & No & No \\
\hline $\begin{array}{l}\text { Assessme } \\
\text { nt Tools } \\
\text { for } \\
\text { Palliative } \\
\text { Care }^{16} \\
2016\end{array}$ & Physician & Yes & No & No & No & Yes & No & No & Yes & Yes & $\begin{array}{l}\text { Yes (not } \\
\text { representative) }\end{array}$ & No \\
\hline
\end{tabular}




\begin{tabular}{|c|c|c|c|c|c|c|c|c|c|c|c|c|}
\hline $\begin{array}{l}\text { Technical } \\
\text { Brief Title } \\
\text { and Year } \\
\text { Accepted }\end{array}$ & Nominator & $\begin{array}{l}\text { Interventi } \\
\text { on study? }\end{array}$ & $\begin{array}{l}\text { Reported } \\
\text { on } \\
\text { outcomes } \\
\text { ? }\end{array}$ & $\begin{array}{l}\text { Does it } \\
\text { make } \\
\text { recom } \\
\text { mendat } \\
\text { ions? }\end{array}$ & $\begin{array}{l}\text { Graded } \\
\text { SOE }\end{array}$ & $\begin{array}{l}\text { Risk } \\
\text { of } \\
\text { Bias } \\
\text { Asse } \\
\text { ssme } \\
\text { nt }\end{array}$ & $\begin{array}{l}\text { Meta- } \\
\text { analys } \\
\text { is }\end{array}$ & $\begin{array}{l}\text { Formal } \\
\text { Qualitat } \\
\text { ive } \\
\text { Method } \\
\text { s }\end{array}$ & $\begin{array}{l}\text { KI } \\
\text { contribut } \\
\text { ed to } \\
\text { findings }\end{array}$ & $\begin{array}{l}\text { Performed } \\
\text { grey } \\
\text { literature } \\
\text { searches }\end{array}$ & $\begin{array}{l}\text { Major issues } \\
\text { with KI } \\
\text { interviews } \\
\text { discussed in } \\
\text { peer review } \\
\text { feedback }\end{array}$ & $\begin{array}{l}\text { Major issues } \\
\text { with scoping } \\
\text { of review } \\
\text { discussed in } \\
\text { peer review } \\
\text { feedback }\end{array}$ \\
\hline $\begin{array}{l}\text { Pharmacol } \\
\text { ogic and } \\
\text { Nonpharm } \\
\text { acologic } \\
\text { Treatment } \\
\text { s for } \\
\text { Posttraum } \\
\text { atic Stress } \\
\text { Disorder: } \\
\text { Groundwo } \\
\text { rk for a } \\
\text { Publicly } \\
\text { Available } \\
\text { Repository } \\
\text { of } \\
\text { Randomiz } \\
\text { ed } \\
\text { Controlled } \\
\text { Trial } \\
\text { Data }{ }^{17} \\
2019\end{array}$ & $\begin{array}{l}\text { National } \\
\text { Center for } \\
\text { Posttraumati } \\
\text { c Stress } \\
\text { Disorder }\end{array}$ & Yes & Yes & No & No & No & No & No & No & No & No & No \\
\hline $\begin{array}{l}\text { Treatment } \\
\text { for Acute } \\
\text { Pain: An } \\
\text { Evidence } \\
\text { Map }^{18} \\
2019\end{array}$ & Unsure & Yes & No & No & No & No & No & No & Yes & Yes & $\begin{array}{l}\text { Yes (not enough } \\
\text { info) }\end{array}$ & $\begin{array}{l}\text { Yes } \\
\text { (intervention) }\end{array}$ \\
\hline
\end{tabular}




\begin{tabular}{|c|c|c|c|c|c|c|c|c|c|c|c|c|}
\hline $\begin{array}{l}\text { Technical } \\
\text { Brief Title } \\
\text { and Year } \\
\text { Accepted }\end{array}$ & Nominator & $\begin{array}{l}\text { Interventi } \\
\text { on study? }\end{array}$ & $\begin{array}{l}\text { Reported } \\
\text { on } \\
\text { outcomes } \\
?\end{array}$ & $\begin{array}{l}\text { Does it } \\
\text { make } \\
\text { recom } \\
\text { mendat } \\
\text { ions? }\end{array}$ & $\begin{array}{l}\text { Graded } \\
\text { SOE }\end{array}$ & $\begin{array}{l}\text { Risk } \\
\text { of } \\
\text { Bias } \\
\text { Asse } \\
\text { ssme } \\
\text { nt }\end{array}$ & $\begin{array}{l}\text { Meta- } \\
\text { analys } \\
\text { is }\end{array}$ & $\begin{array}{l}\text { Formal } \\
\text { Qualitat } \\
\text { ive } \\
\text { Method } \\
\text { s }\end{array}$ & $\begin{array}{l}\text { KI } \\
\text { contribut } \\
\text { ed to } \\
\text { findings }\end{array}$ & $\begin{array}{l}\text { Performed } \\
\text { grey } \\
\text { literature } \\
\text { searches }\end{array}$ & $\begin{array}{l}\text { Major issues } \\
\text { with KI } \\
\text { interviews } \\
\text { discussed in } \\
\text { peer review } \\
\text { feedback }\end{array}$ & $\begin{array}{l}\text { Major issues } \\
\text { with scoping } \\
\text { of review } \\
\text { discussed in } \\
\text { peer review } \\
\text { feedback }\end{array}$ \\
\hline $\begin{array}{l}\text { Skin } \\
\text { Substitute } \\
\text { s for } \\
\text { Treating } \\
\text { Chronic } \\
\text { Wounds }{ }^{19} \\
2020\end{array}$ & Unsure & Yes & Yes & No & No & Yes & No & No & Yes & Yes & No & $\begin{array}{l}\text { Yes } \\
\text { (population) }\end{array}$ \\
\hline $\begin{array}{l}\text { Impact of } \\
\text { Communit } \\
\text { y Health } \\
\text { Worker } \\
\text { Certificatio } \\
\text { n on } \\
\text { Workforce } \\
\text { and } \\
\text { Service } \\
\text { Delivery } \\
\text { for } \\
\text { Asthma } \\
\text { and Other } \\
\text { Selected } \\
\text { Chronic } \\
\text { Diseases } \\
\end{array}$ & $\begin{array}{l}\text { La Clinica } \\
\text { del Carino } \\
\text { Family } \\
\text { Health } \\
\text { Center }\end{array}$ & No & No & No & No & No & No & No & Yes & Yes & $\begin{array}{l}\text { Yes (not } \\
\text { representative) }\end{array}$ & $\begin{array}{l}\text { Yes } \\
\text { (intervention) }\end{array}$ \\
\hline
\end{tabular}




\begin{tabular}{|c|c|c|c|c|c|c|c|c|c|c|c|c|}
\hline $\begin{array}{l}\text { Technical } \\
\text { Brief Title } \\
\text { and Year } \\
\text { Accepted }\end{array}$ & Nominator & $\begin{array}{l}\text { Interventi } \\
\text { on study? }\end{array}$ & $\begin{array}{l}\text { Reported } \\
\text { on } \\
\text { outcomes } \\
\text { ? }\end{array}$ & $\begin{array}{l}\text { Does it } \\
\text { make } \\
\text { recom } \\
\text { mendat } \\
\text { ions? }\end{array}$ & $\begin{array}{l}\text { Graded } \\
\text { SOE }\end{array}$ & $\begin{array}{l}\text { Risk } \\
\text { of } \\
\text { Bias } \\
\text { Asse } \\
\text { ssme } \\
\text { nt }\end{array}$ & $\begin{array}{l}\text { Meta- } \\
\text { analys } \\
\text { is }\end{array}$ & $\begin{array}{l}\text { Formal } \\
\text { Qualitat } \\
\text { ive } \\
\text { Method } \\
\text { s }\end{array}$ & $\begin{array}{l}\text { KI } \\
\text { contribut } \\
\text { ed to } \\
\text { findings }\end{array}$ & $\begin{array}{l}\text { Performed } \\
\text { grey } \\
\text { literature } \\
\text { searches }\end{array}$ & $\begin{array}{l}\text { Major issues } \\
\text { with KI } \\
\text { interviews } \\
\text { discussed in } \\
\text { peer review } \\
\text { feedback }\end{array}$ & $\begin{array}{l}\text { Major issues } \\
\text { with scoping } \\
\text { of review } \\
\text { discussed in } \\
\text { peer review } \\
\text { feedback }\end{array}$ \\
\hline $\begin{array}{l}\text { Characteri } \\
\text { stics of } \\
\text { Existing } \\
\text { Asthma } \\
\text { Self- } \\
\text { Manageme } \\
\text { nt } \\
\text { Education } \\
\text { Packages }{ }^{2} \\
1 \\
2020\end{array}$ & $\begin{array}{l}\text { Nurse/Nurse } \\
\text { Practioner }\end{array}$ & Yes & Yes & No & No & No & No & No & Yes & Yes & $\begin{array}{l}\text { Yes (not } \\
\text { representative) }\end{array}$ & $\begin{array}{l}\text { Yes } \\
\text { (intervention) }\end{array}$ \\
\hline Percent & & $86 \%$ & $62 \%$ & $14 \%$ & $0 \%$ & $14 \%$ & $0 \%$ & $10 \%$ & $76 \%$ & $81 \%$ & & \\
\hline
\end{tabular}




\section{References}

1. McPheeters M, Davis AM, Taylor JL, et al. Transition care for children with special health needs. Agency for Healthcare Research and Quality (US). 2014; Technical Brief No.: 14-EHC027-EF. PMID: 25057736 .

2. Butler M, Ratner E, McCreedy E, et al. Decision aids for advance care planning: an overview of the state of the science. Agency for Healthcare Research and Quality (US). 2014; Technical Brief No. 14-EHC039-EF. PMID: 25069709.

3. Gold LS, Lee CI, Devine B, et al. Imaging Techniques for Treatment Evaluation for Metastatic Breast Cancer. Agency for Healthcare Research and Quality (US). 2014; Technical Brief No.: 14-EHC044-EF. PMID: 25375016.

4. Gaynes B, Brown C, Lux LJ, et al. Relationship between use of quality measures and improved outcomes in serious mental illness. Agency for Healthcare Research and Quality (US). 2015; Technical Brief No.: 15EHC003-EF. PMID: 25654159.

5. Bridges JF, Berger Z, Austin M, et al. Public Reporting of Cost Measures in Health: An Environmental Scan of Current Practices and Assessment of Consumer Centeredness Agency for Healthcare Research and Quality (US). 2015; Technical Brief No.: 15EHC009-EF. PMID: 25763451.

6. Gaynes BN, Brown C, Lux LJ, et al. Management strategies to reduce psychiatric readmissions. Agency for Healthcare Research and Quality (US). 2015;Technical Brief No.: 15-EHC018-EF. PMID: 26020093.

7. Dufendach KR, Eichenberger JA, McPheeters $\mathrm{ML}$, et al. Core functionality in pediatric electronic health records. Agency for Healthcare Research and Quality (US). 2015; Technical Brief No.: 15-EHC014-EF. PMID: 25950078.
8. Sun F, Oristaglio J, Levy SE, et al. Genetic Testing for Developmental Disabilities, Intellectual Disability, and Autism Spectrum Disorder. Agency for Healthcare Research and Quality (US). 2015; Technical Brief No. 15-EHC024-EF. PMID: 26158183.

9. Leas BF, Sullivan N, Han J, et al. Environmental Cleaning for the Prevention of HealthcareAssociated Infections Agency for Healthcare Research and Quality (US). 2015; Technical Brief No. 15-EHC020-EF. PMID: 26290935.

10. Evans TS, Berkman N, Brown C, et al. Disparities within serious mental illness. Agency for Healthcare Research and Quality (US). 2016; Technical Brief No.: 16EHC027-EF. PMID: 27336120.

11. Shekelle PG, Sarkar U, Shojania K, et al. Patient safety in ambulatory settings. Agency for Healthcare Research and Quality (US). 2016; Technical Brief No.: 16(17)-EHC033EF. PMID: 27854399.

12. Totten AM, Womack DM, Eden KB, et al. Telehealth: mapping the evidence for patient outcomes from systematic reviews. Agency for Healthcare Research and Quality (US). 2016; Technical Brief No.: 16-EHC034-EF. PMID: 27536752.

13. Simmons S, Schnelle J, Slagle J, et al. Resident safety practices in nursing home settings. Agency for Healthcare Research and Quality (US). 2016; Technical Brief No.: 16EHC022-EF. PMID: 27606383.

14. Adam GP, Di M, Cu-Uvin S, et al. Strategies for improving the lives of women aged 40 and above living with HIV/AIDS. Agency for Healthcare Research and Quality (US). 2016; Technical Brief No.: 16(17)-EHC040EF. PMID: 27929614.

15. Chou R, Korthuis PT, Weimer M, et al. Medication-assisted treatment models of care for opioid use disorder in primary care settings. Agency for Healthcare Research and Quality (US). 2016; Technical Brief No.: 16(17)-EHC039-EF. PMID: 28045474. 
16. Aslakson R, Dy S, Wilson R, et al. Assessment Tools for Palliative Care. Agency for Healthcare Research and Quality (US). 2017; Technical Brief No.: 17-EHC007-EF. PMID: 28837305.

17. O’Neil M, McDonagh M, Hsu F, et al. Pharmacologic and Nonpharmacologic Treatments for Posttraumatic Stress Disorder: Groundwork for a Publicly Available Repository of Randomized Controlled Trial Data. Agency for Healthcare Research and Quality (US). 2019; Technical Brief No.: 19-EHC018-EF. PMID: 31145565.

18. Brasure M, Nelson VA, Scheiner S, et al. Treatment for Acute Pain: An Evidence Map. Agency for Healthcare Research and Quality (US). 2019; Technical Brief No.: 19(20)-EHC022-EF. PMID: 31693321.
19. Snyder D, Sullivan N, Margolis D, et al. Skin substitutes for treating chronic wounds. Agency for Healthcare Research and Quality (US). 2020. PMID: 32101391.

20. Ibe CA, Wilson LM, Brodine J, et al. Impact of Community Health Worker Certification on Workforce and Service Delivery for Asthma and Other Selected Chronic Diseases. Agency for Healthcare Research and Quality (US). 2020; Technical Brief No.: 20EHC004-EF. PMID: 32255577.

21. Leas BF, Tipton K, Bryant-Stephens T, et al. Characteristics of Existing Asthma SelfManagement Education Packages. Agency for Healthcare Research and Quality (US). 2020; Technical Brief No.: 20-EHC008. PMID: 32369313. 